Callaghan, C. T., M. B. Lyons, J. M. Martin, R. E. Major, and R. T. Kingsford. 2017. Assessing the reliability of avian biodiversity measures of urban greenspaces using eBird citizen science data. Avian Conservation and Ecology 12(2):12. https://doi.org/10.5751/ACE-01104-120212 Copyright (C) 2017 by the author(s). Published here under license by the Resilience Alliance.

Research Paper

\title{
Assessing the reliability of avian biodiversity measures of urban greenspaces using eBird citizen science data
}

\author{
Corey T. Callaghan ${ }^{1}$, Mitchell B. Lyons ${ }^{1}$, John M. Martin ${ }^{2}$, Richard E. Major ${ }^{3,4}$ and Richard T. Kingsford ${ }^{1}$ \\ ${ }^{1}$ Centre for Ecosystem Science, School of Biological, Earth and Environmental Sciences, UNSW, Sydney, Australia, ${ }^{2}$ Royal Botanic \\ Gardens and Domain Trust, Sydney, Australia, ${ }^{3}$ Australian Museum Research Institute, Australian Museum, Sydney, Australia, \\ ${ }^{4}$ Centre for Ecosystem Science, School of Biological, Earth and Environmental Sciences, Sydney, Australia
}

\begin{abstract}
Urban greenspaces are important areas for biodiversity, serving multiple uses, sometimes including conservation and biodiversity management. Citizen science provides a cheap and potentially effective method of assisting biodiversity management in urban greenspaces. Despite this potential, the minimum amount of citizen science data required to adequately represent a community is largely untested. We used eBird data to test the minimum sampling effort required to be confident in results for three biological metrics, species richness, Shannon diversity, and community composition (Bray-Curtis similarity). For our data, from 30 urban greenspaces in North America, for a 90\% threshold level, a minimum mean number of 210, 33, and 58 checklists were necessary for species richness, Shannon diversity, and community composition, respectively. However, when we eliminated those species that were present in fewer than $5 \%$ of checklists at a given site, there was a marked decrease in mean minimum number of checklists required $(17,9$, and 52, respectively). Depending on the ecological questions of interest, eBird data may be a potentially reliable data source in urban greenspaces. We provide a validation methodology using eBird data, with its associated code in the $\mathrm{R}$ statistical environment, to provide confidence for land managers and community groups managing urban greenspaces.
\end{abstract}

\section{Évaluer la fiabilité du décompte de la diversité aviaire dans les espaces verts urbains en utilisant les données scientifiques recueillis par les citoyens grâce à eBird}

RÉSUMÉ. Les espaces verts urbains sont importants pour la biodiversité, ayant de multiples utilisations, et parfois incluant la gestion de la conservation et de la biodiversité. La science citoyenne est un moyen peu couteux et potentiellement efficace d'aide à la gestion de la biodiversité dans les espaces verts urbains. Malgré ce potentiel, le minimum de données recueillis nécessaire par la science citoyenne demeure non testé. Nous avons utilisé eBird pour recueillir des données afin de tester l'échantillonnage minimum requit afin d'être confiant des résultats de trois matrices biologiques; la richesse, l'indice de diversité Shannon, ainsi que la composition de la communauté (similarité Bray-Curtis). Selon nos données, provenant de 30 espaces verts urbains en Amérique du Nord, pour atteindre un seuil de $90 \%$, un minimum de 210, 33, et 58 listes furent nécessaire pour la richesse, l'indice de diversité Shannon, et la composition de la communauté, respectivement. Par contre, lorsque nous avons éliminé les espèces presents dans moins de $5 \%$ des listes à un site donné, il apparait une diminution marquante de liste requise (17,9, et 52, respectivement). Dépendamment de la question écologique posée, les données d'eBird sont potentiellement une source fiable en ce qui concerne les espaces verts urbains. Nous fournissons une méthodologie de validation des données d'Ebird, incluant le codage associé à l'environnement statistique de R, afin de fournir un outil de confiance pour les gestionnaires de territoires et les groupes communautaires gérant les espaces verts urbains

Key Words: biodiversity; ecological monitoring; minimum sampling effort; species richness; urban ecology; urban greenspace

\section{INTRODUCTION}

Increasing global urbanization requires an improved understanding of urban biodiversity (Marzluff et al. 2008, McDonnell et al. 2009, Marzluff 2017), given the value of urban biodiversity to people (Fuller et al. 2007) and the importance of tracking environmental change (Dearborn and Kark 2010). Birds are particularly useful for measuring biodiversity because they are relatively easy to survey, sensitive to habitat alteration (Croci et al. 2008, Ferenc et al. 2014), and popular with people (Fuller et al. 2007).

Citizen science can provide a cheap and effective method of collecting data (Tulloch et al. 2013, Bonney et al. 2014, Kobori et al. 2016), assisting biodiversity management in urban areas (Kobori and Primack 2003, Evans et al. 2005, Cooper et al. 2007, Kobori et al. 2016). It is increasingly embraced for avian monitoring, e.g., Christmas Bird Counts (National Audubon Society 2012), Breeding Bird Survey (Sauer et al. 2015), and eBird (Sullivan et al. 2009, 2014), and can provide data on the distribution and abundance of urban birds (McCaffrey 2005). The value of citizen science data in conservation biology is increasing in popularity and impact (e.g., Bonney et al. 2009, 2014, Bonter and Cooper 2012, Dickinson et al. 2012, Ellwood et al. 2017). Accompanying this increase in the use of citizen science, there is also an increasing focus on the validation of citizen science projects across disciplines (Delaney et al. 2008, Kremen et al.

Address of Correspondent: Corey T. Callaghan, Centre for Ecosystem Science, School of Biological, Earth and Environmental Sciences, UNSW, Sydney NSW 2052, Australia, c.callaghan@unsw.edu.au 
2011, Nagy et al. 2012, Szabo et al. 2012, Tregidgo et al. 2013, van Strien et al. 2013, Isaac et al. 2014, Vianna et al. 2014, Miller et al. 2016, van der Velde et al. 2017).

Despite their potential and growing popularity, data from citizen science projects are commonly questioned because of spatial and temporal biases (Boakes et al. 2010, Tulloch et al. 2013, Bird et al. 2014). Commonly, there are a disproportionate number of sightings from urban areas and roadways (Kelling et al. 2015a), and on weekends (Courter et al. 2013). However, statistical solutions help account for these biases (Fink et al. 2010, Bird et al. 2014, Sullivan et al. 2017) and, when sampling effort is high, e.g., in urban areas, spatial bias becomes negligible if the ecological questions are within that sampling bias (Callaghan and Gawlik 2015).

The eBird project (Sullivan et al. 2009, 2014) enlists volunteers to submit bird sightings, verified by regional reviewers based on the spatiotemporal coordinates of the sighting (Wood et al. 2011). For each species, a volunteer submits either a count of the species or alternatively its presence at a particular site, signified by an "X." Sites are either a personal location determined by the volunteer, or an eBird-defined hotspot, which is a nominated location, known for birding. Since its inception in 2002, eBird has grown to be the largest biodiversity citizen science project in the world, with $>400$ million observations ( $>70$ million observations in 2015; Sullivan et al. 2017).

Within urban ecosystems, traditional biodiversity concepts, e.g., scale, hierarchy, or fragmentation, can be used to manage biodiversity (Savard et al. 2000), in which case ecological questions are often related to a measure of richness or composition of the birds present. Surveys should therefore fully represent avian communities and this can be achieved by statistically adjusting site occupancy using species detection probabilities, or determining minimum sampling effort (de Solla et al. 2005). Importantly, the question still remains as to how much citizen science data is required to adequately represent a community, i.e., minimum sampling effort. This is particularly important in studies relying on untrained observers with a range of experience, which may inflate the importance of rare species or neglect common species, and as a consequence, misrepresent community structure. The assessment of minimum data requirements can provide confidence for conservation management decisions. Such techniques need to be readily available for land managers and community groups seeking to use citizen science data for monitoring urban avifauna.

The aims of this study were twofold: (1) to assess a methodology for calculating the minimum amount of citizen science data for reliable biodiversity estimates of an avian community, and (2) to provide guidelines and programming code for calculation of minimum eBird data thresholds at a particular site (in the $\mathrm{R}$ statistical language; R Core Team 2016), so that these data can be readily used in management decision making. We focused on urban greenspaces, using eBird data, incorporating the project's standard protocols and filters on data quality (Sullivan et al. 2009, 2014). Specifically, we identified minimum thresholds, using commonly employed metrics of biodiversity: species richness, Shannon diversity (Magurran 1988), and community composition.

\section{METHODS}

\section{Study sites}

The majority of observations submitted through eBird originate in North America, however the use of this application is growing in popularity in other parts of the world (Wood et al. 2011). For this study, we first investigated urban greenspaces in North America, i.e., United States and Canada, and then compared these results with urban greenspaces from other parts of the world.

Candidate greenspaces were randomly chosen from the top 6 urban centers by population in Canada and the top 27 from the United States (Demographia World Urban Areas 2016). We used the eBird "explore hotspots" interface to select candidate greenspaces in each urban center. Candidate greenspaces needed to meet the following criteria: (1) they contained a minimum of 100 eBird checklists between 1 January 2010 and 31 December 2016, which met our statistical criteria; (2) the greenspace was surrounded by urbanized land cover, rather than by a major water body or another greenspace; and (3) the greenspace contained only one eBird "hotspot" pin. If more than one candidate greenspace occurred in an urban center, we selected only the one with the most checklists. Our final North American dataset consisted of 30 greenspaces (Appendix 1), which were then compared with 5 global greenspaces (Appendix 1) chosen using the same criteria.

\section{Statistical analysis}

Checklist data (eBird Basic Dataset version ebd_relFeb-2017) were downloaded from eBird (http://ebird.org/ebird/data/ download). We excluded "incomplete" checklists because, by definition, these did not adequately sample the community. For our purposes, checklists were considered "incomplete" if they recorded data on only a subset of species, or if they reported presence/absence data for a single species, rather than abundance estimates for every species. We also limited checklists used according to the following criteria: (1) checklists were excluded if they had associated "group-identifiers" because these represent duplicated checklists, (2) checklists were excluded if they recorded a travel distance $>10 \mathrm{~km}$, (3) checklists were included only if the recording duration was between 5 and 240 minutes, and (4) checklists were included only if they followed the "stationary," "travelling," or "exhaustive" protocols (see Sullivan et al. 2014).

The analyses were performed on two datasets. First, we used the complete (after the above filtering) dataset, and second, we removed species from each greenspace that were recorded on fewer than $5 \%$ of checklists at that greenspace. The second set of analyses was included to potentially limit the impacts of vagrants or erroneous identification on the analysis. We further acknowledge that this may eliminate difficult-to-detect species from the analysis (e.g., Rallidae), but this is a problem with many survey protocols, not restricted to citizen science.

We used three metrics to identify thresholds for the minimum number of checklists required: species richness, Shannon diversity, and community composition, i.e., autosimilarity (Cao et al. 2001, Schneck and Melo 2010). For each metric, we calculated the number of checklists required to achieve $70 \%, 80 \%$, and $90 \%$ of the metric values calculated using all of the checklists 
separately for each greenspace. These are pragmatic levels of "completeness" but represent varying levels of sampling confidence, which might be acceptable depending on the ecological question of interest. All analyses were performed in the R statistical computing environment (R Core Team 2016). Species richness was defined as the total number of species at a site. Species diversity was measured using Shannon diversity, calculated using the "diversity" function from the vegan package (Oksanen et al. 2016). Community composition was based on the Bray-Curtis similarity index using the "autosimi" function from the CommEcol package (Melo 2016), modified to sample with replacement. We used a bootstrapping framework to calculate each of the metrics 1000 times, for each of $\{1,2,3, \ldots, n\}$ checklists at each greenspace, using a random subsample (with replacement) of the checklists each time. These sample distributions were then used to calculate the threshold values (mean and confidence interval) for each metric, for each greenspace. We also used the sample distributions to calculate an overall mean and confidence interval for plotting accumulation curves for each metric. We also tested for correlations between greenspace area and the number of checklists that met specified thresholds, using Kendall's $\tau_{a}$ correlation test (Newson 2002), because of the skewed distribution of greenspace areas.

Because our main analysis focused on North American greenspaces, we first analyzed greenspaces based on seasonal datasets. Forty-four greenspace/season combinations had $>100$ checklists. The results for these 44 greenspace/season combinations are presented in Appendix 2. Ultimately, there was little difference among seasons with regard to minimum sampling thresholds (species richness $-\mathrm{F}=1.046, \mathrm{P}=0.373$; Shannon diversity $-\mathrm{F}=$ $0.311, \mathrm{P}=0.817$; composition $-\mathrm{F}=1.479, \mathrm{P}=0.221$ ). Accordingly, the results presented in the main text are cumulative results, i.e., over the entire time frame without regard to season.

We also investigated the merit of analyzing the data based on survey duration, rather than simply the number of checklists. However, sampling duration was highly correlated with the number of checklists at a site $(\mathrm{z}=6.14, \mathrm{P}<0.001$; Appendix 3$)$ and so here we present data only on the number of checklists. We selected number of checklists as the metric because it is intuitively simpler, and this is a key consideration when developing practical tools for land managers.

\section{Analytical code and tutorial}

To demonstrate how land managers can validate eBird data for use in greenspace avifaunal monitoring, we include a worked example for one selected greenspace, Buena Vista Park, San Francisco, California, employing the aforementioned calculations of the biodiversity metrics.

\section{RESULTS}

A total of 13,629 checklists were included in the analyses, ranging from 103 at Lake Eola, Orlando, Florida to 1320 at A.D. Barnes Park, Miami, Florida. The number of checklists at a greenspace was not correlated with population size of the urban center $\left(\mathrm{R}^{2}=\right.$ $0.006)$, or area $\left(\mathrm{km}^{2}\right)$ of the urban center $\left(\mathrm{R}^{2}=0.005\right)$.

For all three metrics, the average number of checklists increased with the desired threshold (Fig. 1, Table 1). The checklist thresholds for the three metrics also varied, with Shannon diversity the least sensitive to the number of checklists, and species richness the most sensitive (Fig. 1). For a 90\% threshold level, a minimum mean
Fig. 1. The number of checklists (2010-2016), necessary to meet $70 \%, 80 \%$, and $90 \%$ thresholds for 30 sites throughout Canada and the United States (Table A1.1) for (a) species richness, (b) Shannon diversity, and (c) community composition (Bray-Curtis similarity). Separate analyses are provided for the full dataset, and for those species recorded on $>5 \%$ of all checklists at the site.
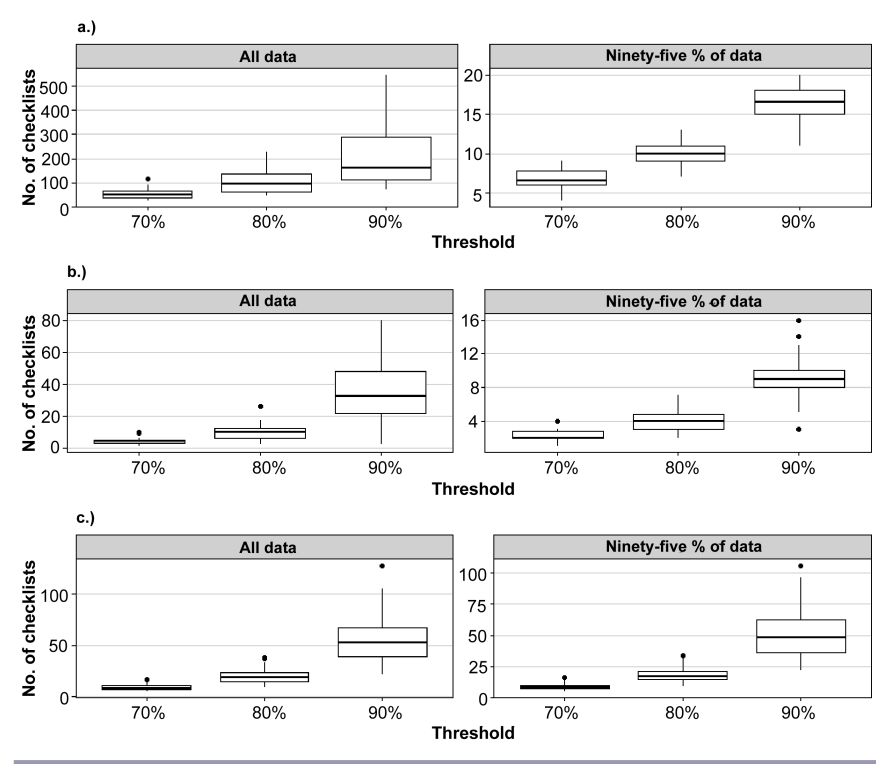

Table 1. The minimum number of checklists (2010-2016), necessary to meet $70 \%, 80 \%$, and $90 \%$ thresholds for 30 greenspaces throughout Canada and the United States (Table A1.1) for species richness, species diversity, and community composition (BrayCurtis similarity). Separate analyses are provided for the full dataset, and for those species recorded on $>5 \%$ of all checklists at the site.

\begin{tabular}{|c|c|c|c|c|}
\hline \multirow[b]{2}{*}{ Threshold } & \multicolumn{2}{|c|}{ All data } & \multicolumn{2}{|c|}{$95 \%$ of data } \\
\hline & $\begin{array}{l}\text { Mean } \pm \text { SD } \\
\text { Checklists }\end{array}$ & Range & $\begin{array}{l}\text { Mean } \pm \text { SD } \\
\text { Checklists }\end{array}$ & Range \\
\hline & \multicolumn{4}{|c|}{ Species Richness } \\
\hline $70 \%$ & $54.63 \pm 22.83$ & $25-114$ & $6.7 \pm 1.3$ & $4-9$ \\
\hline $80 \%$ & $104.53 \pm 51.75$ & $45-226$ & $10.01 \pm 1.7$ & $7-13$ \\
\hline $90 \%$ & $210.07 \pm 129.13$ & $70-548$ & $16.7 \pm 2.3$ & $11-20$ \\
\hline & \multicolumn{4}{|c|}{ Species Diversity } \\
\hline $70 \%$ & $4.13 \pm 2.01$ & $1-10$ & $2.33 \pm 0.71$ & $1-4$ \\
\hline $80 \%$ & $9.67 \pm 5.06$ & $2-26$ & $4.01 \pm 1.17$ & $2-7$ \\
\hline $90 \%$ & $32.27 \pm 18.45$ & $2-80$ & $9.2 \pm 2.8$ & $3-16$ \\
\hline & \multicolumn{4}{|c|}{ Community Composition } \\
\hline $70 \%$ & $9.43 \pm 3.36$ & $5-17$ & $8.80 \pm 2.86$ & $5-16$ \\
\hline $80 \%$ & $20.03 \pm 7.38$ & $9-38$ & $18.33 \pm 6.24$ & $9-34$ \\
\hline $90 \%$ & $57.7 \pm 24.76$ & $22-128$ & $52.0 \pm 20.68$ & $22-106$ \\
\hline
\end{tabular}

number of 210,33 , and 58 checklists were necessary for species richness, Shannon diversity, and community composition, respectively (Table 1). However, when we eliminated those species that were present in fewer than $5 \%$ of checklists at a given site, there 
Fig. 2. Relationships between hotspot area and the number of checklists to meet the necessary thresholds included in the analysis for (a) species richness, (b) Shannon diversity, and (c) community composition (Bray-Curtis similarity) for $70 \%$ (circles), $80 \%$ (triangles), and 90\% (squares) threshold levels. Separate analyses are provided for the full dataset, and for those species recorded on $>5 \%$ of all checklists at the site.
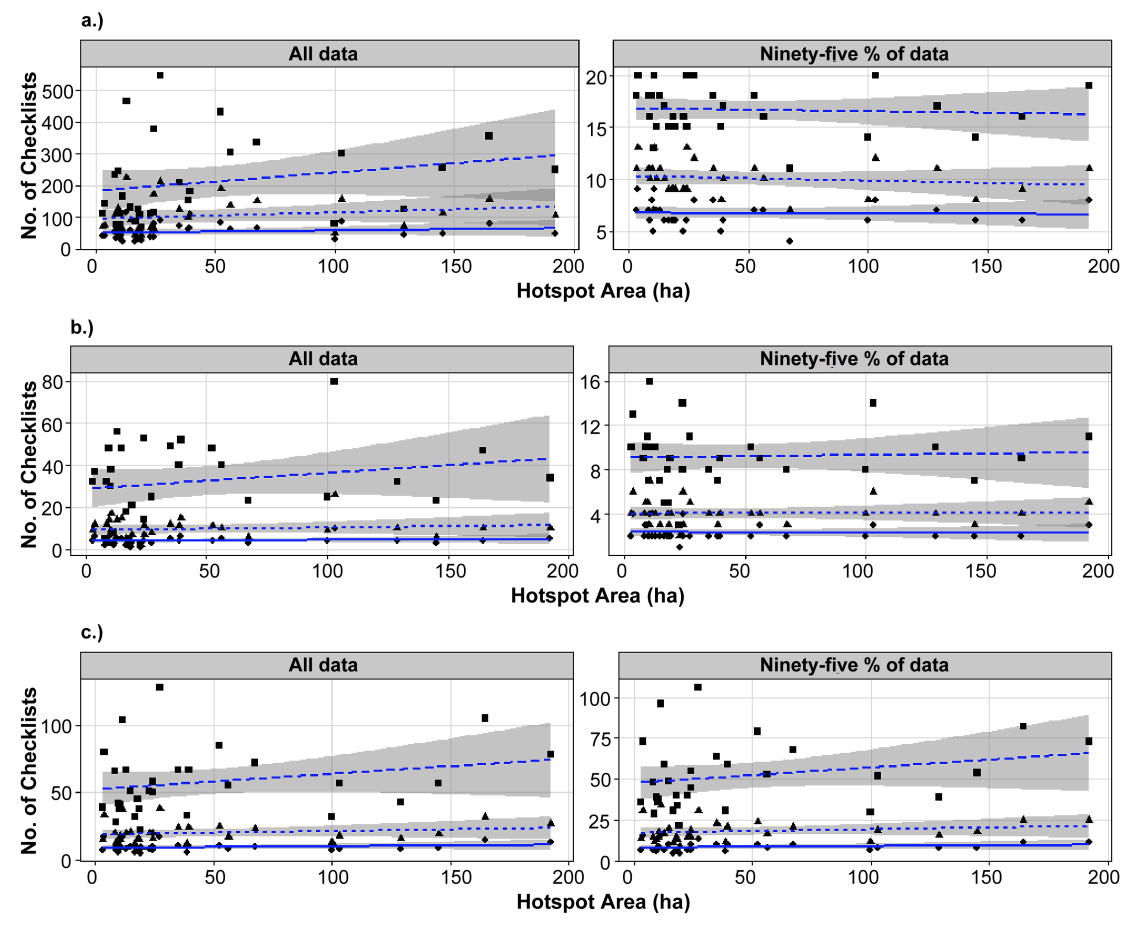

was a marked decrease in mean minimum number of checklists required to meet the $90 \%$ threshold for species richness (17: $92 \%$ decrease) and Shannon diversity (9: 73\% decrease) but not for community composition (52; $10 \%$ decrease; Fig. 1, Table 1$)$. Similar patterns were upheld for the $70 \%$ and $80 \%$ threshold levels (Table 1). Appendix 4 shows the individual accumulation curves for each greenspace. There was no significant relationship between greenspace area (Appendix 1) and number of checklists required to meet thresholds for species richness, Shannon diversity, or community composition (Fig. 2, Table 2).

\section{Global comparison}

Five greenspaces outside North America that met our criteria were analyzed. They comprised a total of 844 checklists, ranging from 142 at the Royal Botanic Gardens, Melbourne, Australia to 181 at Parque Rufino Tamayo, Nuevo Leon, Mexico. The results were similar to those from North American greenspaces (Fig. 3, Table 3). At a 90\% threshold level, 103, 17, and 33 mean checklists were required for species richness, Shannon diversity, and community composition, respectively. However, when eliminating the species that did not occur on greater than $5 \%$ of checklists; the mean number of checklists necessary dropped to 12,6 , and 31 , respectively (Table 3 ).

\section{Tutorial example}

Consistent with the generalized results, our example greenspace, Buena Vista Park, San Francisco, California, generated different accumulation curves depending upon the inclusion of infrequently
Table 2. The relationship between greenspace area and the minimum number of checklists necessary to meet $70 \%, 80 \%$, and $90 \%$ threshold levels for 30 greenspaces throughout Canada and the United States (Table A1.1). The summary statistics show no significant relationship between greenspace area and minimum number of checklists both among threshold levels and across separate analyses - (1) the full dataset and (2) those species recorded on $>5 \%$ of all checklists at the site-for species richness, species diversity, and community composition (Bray-Curtis similarity).

\begin{tabular}{|c|c|c|c|c|}
\hline \multirow[b]{2}{*}{ Threshold } & \multicolumn{2}{|c|}{ All data } & \multicolumn{2}{|c|}{$95 \%$ of data } \\
\hline & z-statistic & p-value & z-statistic & p-value \\
\hline & \multicolumn{4}{|c|}{ Species Richness } \\
\hline $70 \%$ & 1.61 & 0.11 & -0.77 & 0.44 \\
\hline $80 \%$ & 1.86 & 0.06 & -1.37 & 0.17 \\
\hline \multirow[t]{2}{*}{$90 \%$} & 1.95 & 0.05 & -0.87 & 0.38 \\
\hline & \multicolumn{4}{|c|}{ Species Diversity } \\
\hline $70 \%$ & 0.36 & 0.72 & -0.60 & 0.55 \\
\hline $80 \%$ & 0.13 & 0.90 & -0.47 & 0.64 \\
\hline \multirow[t]{2}{*}{$90 \%$} & 0.93 & 0.35 & -0.47 & 0.64 \\
\hline & \multicolumn{4}{|c|}{ Community Composition } \\
\hline $70 \%$ & 1.16 & 0.25 & 1.44 & 0.15 \\
\hline $80 \%$ & 1.25 & 0.21 & 1.61 & 0.11 \\
\hline $90 \%$ & 1.60 & 0.11 & 1.68 & 0.09 \\
\hline
\end{tabular}


Fig. 3. The number of checklists (2010-2016), necessary to meet $70 \%, 80 \%$, and $90 \%$ thresholds for 5 global sites (Table A1.2) for (a) species richness, (b) Shannon diversity, and (c) community composition (Bray-Curtis similarity). Separate analyses are provided for the full dataset, and for those species recorded on $>5 \%$ of all checklists at the site.
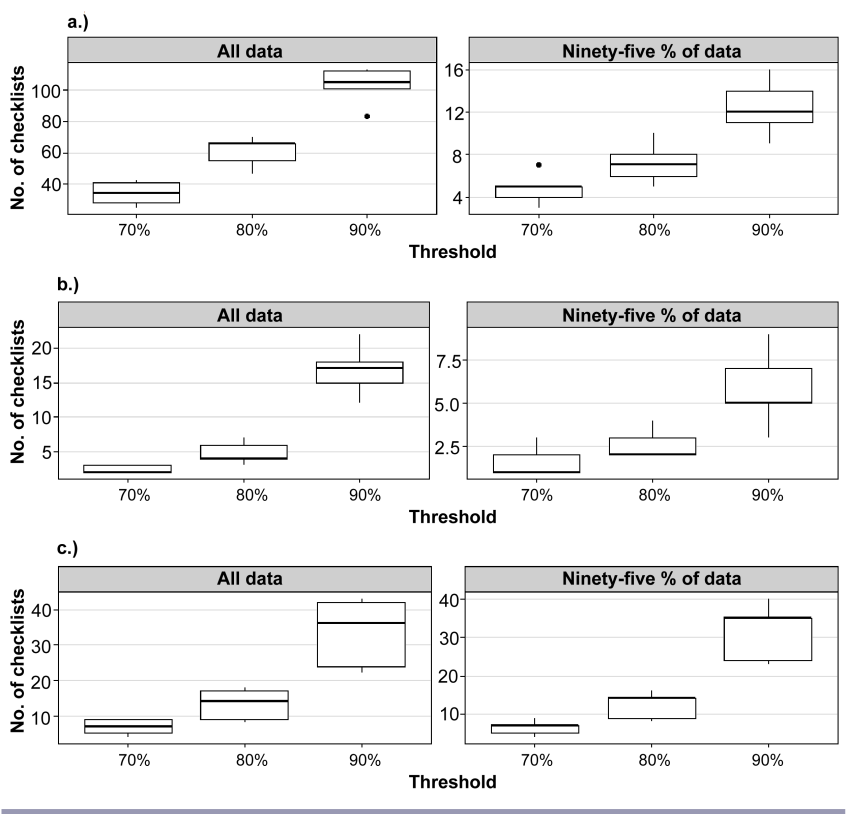

Table 3. The minimum number of checklists (2010-2016), necessary to meet $70 \%, 80 \%$, and $90 \%$ thresholds for five global greenspaces (Table A1.2) that were compared to the North American analysis. Results are shown for species richness, species diversity, and community composition (Bray-Curtis similarity). Separate analyses are provided for the full dataset, and for those species recorded on $>5 \%$ of all checklists at the site.

\begin{tabular}{|c|c|c|c|c|}
\hline \multirow[b]{2}{*}{ Threshold } & \multicolumn{2}{|c|}{ All data } & \multicolumn{2}{|c|}{$95 \%$ of data } \\
\hline & $\begin{array}{c}\text { Mean } \pm \text { SD } \\
\text { Checklists }\end{array}$ & Range & $\begin{array}{l}\text { Mean } \pm \text { SD } \\
\text { Checklists }\end{array}$ & Range \\
\hline & \multicolumn{4}{|c|}{ Species Richness } \\
\hline $70 \%$ & $34.0 \pm 7.6$ & $25-42$ & $4.8 \pm 1.5$ & $3-7$ \\
\hline $80 \%$ & $60.6 \pm 9.9$ & $46-70$ & $7.2 \pm 1.9$ & $5-10$ \\
\hline \multirow[t]{2}{*}{$90 \%$} & $102.8 \pm 12.1$ & $83-113$ & $12.4 \pm 2.7$ & $9-16$ \\
\hline & \multicolumn{4}{|c|}{ Species Diversity } \\
\hline $70 \%$ & $2.4 \pm 0.55$ & $2-3$ & $1.6 \pm 0.9$ & $1-3$ \\
\hline $80 \%$ & $4.8 \pm 1.64$ & $3-7$ & $2.6 \pm 0.89$ & $2-4$ \\
\hline \multirow[t]{2}{*}{$90 \%$} & $16.8 \pm 3.7$ & $12-22$ & $5.8 \pm 2.3$ & $3-9$ \\
\hline & \multicolumn{4}{|c|}{ Community Composition } \\
\hline $70 \%$ & $6.8 \pm 2.3$ & $4-9$ & $6.4 \pm 1.95$ & $4-9$ \\
\hline $80 \%$ & $13.2 \pm 4.55$ & $8-18$ & $12.2 \pm 3.49$ & $8-16$ \\
\hline $90 \%$ & $33.4 \pm 9.89$ & $22-43$ & $31.4 \pm 7.5$ & $23-40$ \\
\hline
\end{tabular}

recorded species (Fig. 4). We found that the number of checklists required to meet $70 \%, 80 \%$, and $90 \%$ thresholds for species richness was 34, 68, and 140, respectively (Fig. 4a) for all data,
Fig. 4. Accumulation curves for (a) species richness with all data, (b) species richness with infrequently recorded species excluded, (c) species diversity with all data, (d) species diversity with infrequently recorded species excluded, (e) community composition with all data, and (f) community composition with infrequently species excluded, for our example greenspace, Buena Vista Park, San Francisco, California. Results are shown for both analyses, all the data, and for those species recorded on $>5 \%$ of all checklists at the site. See Appendix 5 for directions and coding to calculate the accumulation curves.
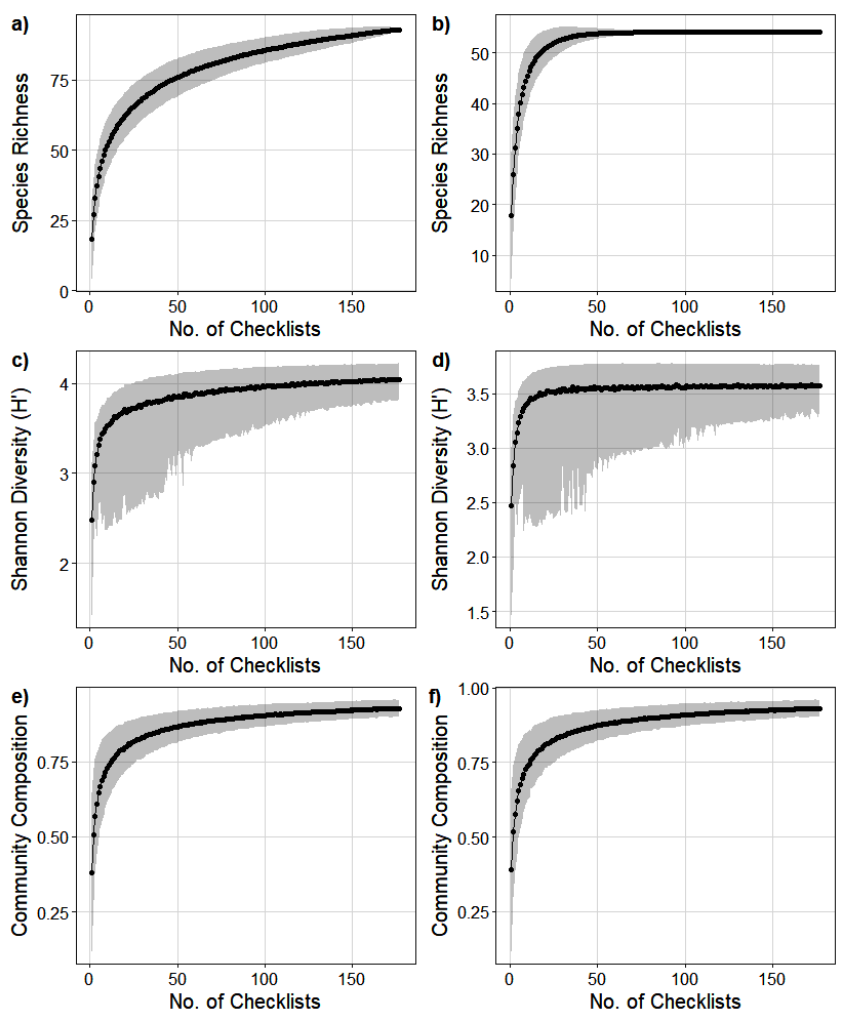

but 6,9 , and 15 when removing species that were recorded on fewer than 5\% of checklists (Fig. 4b). For Shannon diversity, the necessary number of checklists was 2,5 , and 16 for respective thresholds for all data (Fig. 4c), and 2, 3, and 5 when infrequently recorded species were excluded (Fig. 4d). For community composition, the number of checklists was 6, 12, 32 (Fig. 4e) and 6, 11, 30 (Fig. 4f) for the same thresholds and for all data and when infrequently recorded species were excluded, respectively. Details and coding instructions for Buena Vista Park are provided in Appendix 5. The example is available as an .HTML tutorial, as well as a text file that can be directly executed within R.

\section{DISCUSSION}

There was a marked decrease in the minimum number of checklists required to adequately sample a greenspace, depending on whether species that occurred in fewer than $5 \%$ of site checklists were included. This result was most obvious for species richness (Fig. 1, Table 1). This suggests that birders, specifically eBirders, continue to find new birds for local patches over 
extended time periods, hence making the minimum number of checklists required to fully sample the avian community in North America (i.e., species richness) extremely high (55, 105, and 210) for $70 \%, 80 \%$, and $90 \%$ thresholds. However, if the particular research or monitoring objective does not require inclusion of the rare, transient, or vagrant species that might be present only in fewer than $5 \%$ of surveys, the required number of checklists dropped dramatically to 7,10 , and 17 for the respective thresholds of species richness. This decrease was also obvious for species diversity and community composition, but the minimum number of checklists for those thresholds were far less. These results highlighted that eBird may be a potentially useful tool to measure Shannon diversity and community composition, i.e., autosimilarity, in urban greenspaces, but less useful for measuring species richness. However, for coarse monitoring, it is often the "core," i.e., common, set of species that are of interest (Pearman and Weber 2007). Tracking environmental change often relies on the response of common species for which effect size is detectable, rather than the response of rare species for which there is high stochastic variation. If useful monitoring objectives to inform wildlife management can be framed without incorporating species that are observed in fewer than $5 \%$ of records, relatively few checklists are required to adequately monitor the community. Thus, eBird would be an effective method for land managers or community groups to use at their sites of interest, accompanied by promotional activity to encourage birders to conduct enough surveys per year over multiple years to monitor changes in community composition and species diversity. We acknowledge the inherent differences in eBird checklists, e.g., time spent surveying, distance covered, observer skills (Kelling et al. 2015b). We accounted for this variation by employing a random permutation or bootstrap approach, with sufficient resampling $(\geq 1000)$, improving our confidence.

Our analysis highlighted that the number of checklists for adequate sampling of a site varied depending on the (i) desired threshold level, (ii) metric of interest, i.e., richness, diversity, or community composition, (iii) site of interest, and (iv) completeness of the community. Determining minimum sampling effort will depend on the objectives of land managers of urban greenspaces, in relation to management of the greenspace. For instance, for Buena Vista Park, San Francisco, California, our analysis identified that a minimum of 140 checklists were required to have high confidence in species richness assessment for the period 2010-2016, compared to only 16 or 32 checklists, respectively, if Shannon diversity or community composition was the metric of interest. Hence, the number of checklists vastly differs based on the potential management goals and actions potentially being tracked (Fig. 4 and Appendix 5). Calculation of this assessment may be achieved reasonably simply, anywhere in the world, where there are sufficient data collected, reflecting the minimum requirements identified in our study (see Appendix 5).

Our study only investigated urban greenspaces, which are generally small and confined, compared with large-scale natural areas, such as national parks, where the precise location of a checklist may have considerable uncertainty and importance for conservation and management decisions. Furthermore, urban environments typically have lower species diversity and higher individual abundance than natural areas (Blair 1996, Chace and Walsh 2006). Despite this, eBird data may be useful for characterizing bird communities in natural and agricultural areas where there are sufficient data, such as waterbird impoundments (Sullivan et al. 2017), regularly visited camping areas or walking tracks, or regional assessments. However, given these would generally have higher richness and diversity, we would expect a higher number of checklists necessary to sample the community. We found no significant difference among seasons in our preliminary analysis allowing us to pool data across seasons, neglecting interannual differences in sampling. However, practitioners should investigate the temporal frequency of checklists submitted for a site to ensure that they are comprehensive over the whole survey period (e.g., Boakes et al. 2010, Courter et al. 2013), before analyzing community change over time.

Bird assemblage data, recorded through eBird, are increasingly being analyzed ( $>135$ publications), addressing broad scale questions such as migration (Fink et al. 2013) and phenology (Hurlbert and Liang 2012). Our analyses can allow managers and community groups of urban greenspaces to characterize bird community richness (Yoccoz et al. 2001) to inform their decision making. Such basic data on biodiversity can provide a baseline for conservation, especially where there is limited funding, e.g., the tropics (Soulé and Kohm 1989). Interestingly, the necessary number of checklists for the five global greenspaces (Table A1.2) was roughly half of those for our analysis of 30 North American greenspaces (Table A1.1). It is possible that this is influenced by the overall richness in a given region, but further research is needed. Ultimately, this comparison highlights the potential global applicability of eBird data to assess biodiversity metrics in urban greenspaces. However, future studies should expand the global scope of these results. The power of these data are likely to increase, with the growth in popularity of smart devices and mobile phone/data coverage, allowing greater numbers of volunteer contributions to eBird (Wood et al. 2011, Sullivan et al. 2014). Coupled with a global rise in avitourism (Steven et al. 2015), eBird data can be useful for more sophisticated applications, including assessing changes in population size (e.g., Walker and Taylor 2017) and density estimates of species at specific sites.

With the increase of citizen science validation (Bonter and Cooper 2012, Callaghan and Gawlik 2015, Jackson et al. 2015), and the current prevalence of citizen science in scientific literature (Tulloch et al. 2013, Theobald et al. 2015), practitioners must be aware of critical steps to take when using citizen science data. Our analyses of eBird data identified credible thresholds for characterizing bird communities in urban greenspaces, implemented using our tutorial. This application of eBird data lays a foundation for land managers, researchers, and urban planners to utilize freely available data and analysis methods to inform their decision making, including potentially tracking environmental change and biodiversity trends. Although we used eBird data to illustrate our points, a similar approach can and should be applied to any citizen science dataset, prior to its use for decision making.

Responses to this article can be read online at: http://www.ace-eco.org/issues/responses.php/1104 


\section{Acknowledgments:}

We thank the numerous contributors to eBird, including the observers, data reviewers, and the project team at the Cornell Lab of Ornithology. CTC received funding from the Stuart Leslie Conference Award/Foundation from Birdlife Australia. Last, we thank anonymous reviewers and the editors for detailed comments that improved this manuscript.

\section{LITERATURE CITED}

Bird, T. J., A. E. Bates, J. S. Lefcheck, N. A. Hill, R. J. Thomson, G. J. Edgar, R. D. Stuart-Smith, S. Wotherspoon, M. Krkosek, J. F. Stuart-Smith, G. T. Pecl, N. Barrett, and S. Frusher. 2014. Statistical solutions for error and bias in global citizen science datasets. Biological Conservation 173:144-154. http://dx.doi. org/10.1016/j.biocon.2013.07.037

Blair, R. B. 1996. Land use and avian species diversity along an urban gradient. Ecological Applications 5:506-519. http://dx.doi. org/10.2307/2269387

Boakes, E. H., P. J. K., McGowan, R. A. Fuller, D. Chang-qing, N. E. Clark, K. O'Connor, and G. M. Mace. 2010. Distorted views of biodiversity: spatial and temporal bias in species occurrence data. PLoS Biology 8:e1000385. http://dx.doi.org/10.1371/ journal.pbio. 1000385

Bonney, R., C. B. Cooper, J. Dickinson, S. Kelling, T. Phillips, K. V. Rosenberg, and J. Shirk. 2009. Citizen science: a developing tool for expanding science knowledge and scientific literacy. Bioscience 59:977-984. http://dx.doi.org/10.1525/bio.2009.59.11.9

Bonney, R., J. L. Shirk, T. B. Phillips, A. Wiggins, H. L. Ballard, A. J. Miller-Rushing, and J. K. Parrish. 2014. Next steps for citizen science. Science 343:1436-1437. http://dx.doi.org/10.1126/ science. 1251554

Bonter, D. N., and C. B. Cooper. 2012. Data validation in citizen science: a case study from Project FeederWatch. Frontiers in Ecology and the Environment 10:305-307. http://dx.doi. org/10.1890/110273

Callaghan, C. T., and D. E. Gawlik. 2015. Efficacy of eBird data as an aid in conservation planning and monitoring. Journal of Field Ornithology 86:298-304. http://dx.doi.org/10.1111/jofo.12121

Cao, Y., D. P. Larsen, and R. M. Hughes. 2001. Evaluating sampling sufficiency in fish assemblage surveys: a similaritybased approach. Canadian Journal of Fisheries and Aquatic Sciences 58:1782-1793. https://doi.org/10.1139/f01-120

Chace, J. F., and J. J. Walsh. 2006. Urban effects on native avifauna: a review. Landscape and Urban Planning 74:46-49. http://dx.doi.org/10.1016/j.landurbplan.2004.08.007

Cooper, C. B., J. Dickinson, T. Phillips, and R. Bonney. 2007. Citizen science as a tool for conservation in residential ecosystems. Ecology and Society 12(2):11. http://dx.doi.org/10.5751/ ES-02197-120211

Courter, J. R., R. J. Johnson, C. M. Stuyck, B. A. Lang, and E. W. Kaiser. 2013. Weekend bias in citizen science data reporting: implications for phenology studies. International Journal of Biometeorology 57:715-720. http://dx.doi.org/10.1007/s00484-012-0598-7
Croci, S., A. Butet, A. Georges, R. Aguejdad, and P. Clergeau. 2008. Small urban woodlands as biodiversity conservation hotspot: a multi-taxon approach. Landscape Ecology 23:1171-1186. http://dx.doi.org/10.1007/s10980-008-9257-0

Dearborn, D. C., and S. Kark. 2010. Motivations for conserving urban biodiversity. Conservation Biology 24:432-440. http://dx. doi.org/10.1111/j.1523-1739.2009.01328.x

Delaney, D. G., C. D. Sperling, C. S. Adams, and B. Leung. 2008. Marine invasive species: validation of citizen science and implications for national monitoring networks. Biological Invasions 10:117-128. http://dx.doi.org/10.1007/s10530-007-9114-0

Demographia World Urban Areas. 2016. Demographia World Urban Areas 12 $2^{\text {th }}$ Annual Edition: 2016:04. Demographia, Belleville, Illinois, USA. [online] URL: http://demographia.com/ db-worldua-intro.pdf

de Solla, S. R., L. J. Shirose, K. J. Fernie, G. C. Barrett, C. S. Brousseau, and C. A. Bishop. 2005. Effect of sampling effort and species detectability on volunteer based anuran monitoring programs. Biological Conservation 121:585-594. http://dx.doi. org/10.1016/j.biocon.2004.06.018

Dickinson, J. L., J. Shirk, D. Bonter, R. Bonney, R. L. Crain, J. Martin, T. Phillips, and K. Purcell. 2012. The current state of citizen science as a tool for ecological research and public engagement. Frontiers in Ecology and the Environment 10:291-297. http://dx.doi.org/10.1890/110236

Ellwood, E. R., T. M. Crimmins, and A. J. Miller-Rushing. 2017. Citizen science and conservation: recommendations for a rapidly moving field. Biological Conservation 208:1-4. http://dx.doi. org/10.1016/j.biocon.2016.10.014

Evans, C., E. Abrams, R. Reitsma, K. Roux, L. Salmonsen, and P. P. Marra. 2005. The neighborhood nestwatch program: participant outcomes of a citizen-science ecological research project. Conservation Biology 19:589-594. http://dx.doi. org/10.1111/j.1523-1739.2005.00s01.x

Ferenc, M., O. Sedláček, and R. Fuchs. 2014. How to improve urban greenspace for woodland birds: site and local-scale determinants of bird species richness. Urban Ecosystems 17:625-640. http://dx.doi.org/10.1007/s11252-013-0328-x

Fink, D., T. Damoulas, and J. Dave. 2013. Adaptive spatiotemporal exploratory models: hemisphere-wide species distributions from massively crowdsourced eBird data. Pages 1284-1290 in Proceedings of the Twenty-Seventh AAAI Conference on Artificial Intelligence (AAAI-13). July 14-18. Bellevue, Washington, USA.

Fink, D., W. M. Hochachka, B. Zuckerberg, D. W. Winkler, B. Shaby, M. A. Munson, G. Hooker, M. Riedewald, D. Sheldon, and S. Kelling. 2010. Spatiotemporal exploratory models for broad-scale survey data. Ecological Applications 20:2131-2147. http://dx.doi.org/10.1890/09-1340.1

Fuller, R. A., K. N. Irvine, P. Devine-Wright, P. H. Warren, and K. J. Gaston. 2007. Psychological benefits of greenspace increase with biodiversity. Biology Letters 3:390-394. http://dx.doi. org/10.1098/rsbl.2007.0149

Hurlbert, A. H., and Z. Liang. 2012. Spatiotemporal variation in avian migration phenology: citizen science reveals effects of 
climate change. PLoS ONE 7(2):e31662. http://dx.doi. org/10.1371/journal.pone.0031662

Isaac, N. J. B., A. J. van Strien, T. A. August, M. P. de Zeeuw, and D. B. Roy. 2014. Statistics for citizen science: extracting signals of change from noisy ecological data. Methods in Ecology and Evolution 10:1052-1060. http://dx.doi.org/10.1111/2041-210X.12254

Jackson, M. M., S. E. Gergel, and K. Martin. 2015. Citizen science and field survey observations provide comparable results for mapping Vancouver Island White-tailed Ptarmigan (Lagopus leucura saxatilis) distributions. Biological Conservation 181:162-172. http://dx.doi.org/10.1016/j.biocon.2014.11.010

Kelling, S., D. Fink, F. A. La Sorte, A. Johnston, N. E. Bruns, and W. M. Hochachka. 2015a. Taking a 'Big Data' approach to data quality in a citizen science project. Ambio 44:601-611. http:// dx.doi.org/10.1007/s13280-015-0710-4

Kelling, S., A. Johnston, W. M. Hochachka, M. Iliff, D. Fink, J. Gerbracht, C. Lagoze, F. A. La Sorte, T. Moore, A. Wiggins, W.K. Wong, C. Wood, and J. Yu. 2015b. Can observation skills of citizen scientists be estimated using species accumulation curves? PLOS ONE 10(10):e0139600. http://dx.doi.org/10.1371/journal. pone. 0139600

Kobori, H., J. L. Dickinson, I. Washitani, R. Sakurai, T. Amano, N. Komatsu, W. Kitamura, S. Takagawa, K. Koyama, T. Ogawar, and A. J. Miller-Rushing. 2016. Citizen science: a new approach to advance ecology, education, and conservation. Ecological Research 31:1-19. http://dx.doi.org/10.1007/s11284-015-1314-y

Kobori, H., and R. B. Primack. 2003. Participatory conservation approaches for satoyama, the traditional forest and agricultural landscape of Japan. Ambio 32:307-311. http://dx.doi. org/10.1579/0044-7447-32.4.307

Kremen, C., K. S. Ullmann, and R. W. Thorp. 2011. Evaluating the quality of citizen-scientist data on pollinator communities. Conservation Biology 25:607-617. http://dx.doi.org/10.1111/ j.1523-1739.2011.01657.x

Magurran, A. E. 1988. Ecological diversity and its measurement. Princeton University Press, Princeton, New Jersey, USA. http:// dx.doi.org/10.1007/978-94-015-7358-0

Marzluff, J. M. 2017. A decadal review of urban ornithology and a prospectus for the future. Ibis 159:1-13. http://dx.doi. org/10.1111/ibi.12430

Marzluff, J. M., E. Shulenberger, W. Endlicher, M. Alberti, G. Bradley, C. Ryan, U. Simon, and C. ZumBrunnen, editors. 2008. Urban ecology: an international perspective on the interaction between humans and nature. Springer, New York. New York, USA. http://dx.doi.org/10.1007/978-0-387-73412-5

McCaffrey, R. 2005. Using citizen science in urban bird studies. Urban Habitats 3:70-86.

McDonnell, M. J., A. K. Hahs, and J. H. Breuste, editors. 2009. Ecology of cities and towns: a comparative approach. Cambridge University Press, New York, New York, USA. http://dx.doi. org/10.1017/CBO9780511609763

Melo, A. S. 2016. CommEcol: community ecology analyses. $R$ package version 1.6.4. R Foundation for Statistical Computing,
Vienna, Austria. [online] URL: https://CRAN.R-project.org/ package $=$ CommEcol

Miller, R. A., N. Paprocki, M. J. Stuber, C. E. Moulton, and J. D. Carlisle. 2016. Short-eared Owl (Asio flammeus) surveys in the North American Intermountain West: utilizing citizen scientists to conduct monitoring across a broad geographic scale. Avian Conservation and Ecology 11(1):3. http://dx.doi.org/10.5751/ ACE-00819-110103

Nagy, C., K. Bardwell, R. F. Rockwell, R. Christie, and M. Weckel. 2012. Validation of a citizen science-based model of site occupancy for Eastern Screech Owls with systematic data in suburban New York and Connecticut. Northeastern Naturalist 19:143-158. http://dx.doi.org/10.1656/045.019.s611

National Audubon Society. 2012. The Christmas bird count historical results. National Audubon Society, New York, New York, USA.

Newson, R. 2002. Parameters behind "nonparametric" statistics: Kendall's tau, Somers' D and median differences. Stata Journal 2:45-64.

Oksanen, J. F., G. Blanchet, M. Friendly, R. Kindt, P. Legendre, D. McGlinn, P. R. Minchin, R. B. O'Hara, G. L. Simpson, P. Solymos, M. Henry, H. Stevens, E. Szoecs, and H. Wagner. 2016. vegan: Community ecology package. $R$ package version $2.4-1$. $\mathrm{R}$ Foundation for Statistical Computing, Vienna, Austria. [online] URL: https://CRAN.R-project.org/package=vegan

Pearmann, R. B., and D. Weber. 2007. Common species determine richness patterns in biodiversity indicator taxa. Biological Conservation 138:109-119. http://dx.doi.org/10.1016/j.biocon.2007.04.005

R Core Team. 2016. R: a language and environment for statistical computing. R Foundation for Statistical Computing, Vienna, Austria.

Sauer, J. R., J. E. Hines, J. E. Fallon, K. L. Pardieck, D. J. Ziolkowski Jr., and W. A. Link. 2015. The North American breeding bird survey, results and analysis 1966-2013. Version 01.30.2015. U.S. Geological Survey, Patuxent Wildlife Research Center, Laurel, Maryland, USA.

Savard, J.-P. L., P. Clergeau, and G. Mennechez. 2000. Biodiversity concepts and urban ecosystems. Landscape and Urban Planning 48:131-142. http://dx.doi.org/10.1016/S0169-2046 (00)00037-2

Schneck, F., and A. S. Melo. 2010. Reliable sample sizes for estimating similarity among macroinvertebrate assemblages in tropical streams. Annales de Limnologie 46:93-100. https://doi. org/10.1051/limn/2010013

Soulé, M. E., and K. A. Kohm. 1989. Research priorities for conservation biology. Island Press, Washington, D.C., USA.

Steven, R., C. Morrison, and J. G. Castley. 2015. Birdwatching and avitourism: a global review of research into its participant markets, distribution and impacts, highlighting future research priorities to inform sustainable avitourism management. Journal of Sustainable Tourism 23:1257-1276. https://doi. org/10.1080/09669582.2014.924955

Sullivan, B. L., J. L. Aycrigg, J. H. Barry, R. E. Bonney, N. Bruns, C. B. Cooper, T. Damoulas, A. A. Dhondt, T. Dietterich, A. 
Farnsworth, D. Fink, J. W. Fitzpatrick, T. Frefericks, J. Gerbracht, C. Gomes, W. M. Hochachka, M. J. Iliff, C. Lagoze, F. A. La Sorte, M. Merrefield, W. Morris, T. B. Phillips, M. Reynolds, A. D. Rodewald, K. V. Rosenberg, N. M. Trautmann, A. Wiggins, D. W. Winkler, W. K. Wong, C. L. Wood, J. Yu, and S. Kelling. 2014. The eBird enterprise: an integrated approach to development and application of citizen science. Biological Conservation 169:31-40. http://dx.doi.org/10.1016/j.biocon.2013.11.003

Sullivan, B. L., T. Phillips, A. A. Dayer, C. L. Wood, A. Farnsworth, M. J. Iliff, I. J. Davies, A. Wiggins, D. Fink, and W. M. Hochachka. 2017. Using open access observational data for conservation action: a case study for birds. Biological Conservation 208:5-14. http://dx.doi.org/10.1016/j.biocon.2016.04.031

Sullivan, B. L., C. L. Wood, M. J. Iliff, R. E. Bonney, D. Fink, and S. Kelling. 2009. eBird: A citizen-based bird observation network in the biological sciences. Biological Conservation 142:2282- 2292. http://dx.doi.org/10.1016/j.biocon.2009.05.006

Szabo, J. K., R. A. Fuller, and H. P. Possingham. 2012. A comparison of estimates of relative abundance from a weakly structured mass-participation bird atlas survey and a robustly designed monitoring scheme. Ibis 154:468-479. http://dx.doi. org/10.1111/j.1474-919X.2012.01229.X

Theobald, E. J., A. K. Ettinger, H. K. Burgess, L. B. DeBey, N. R. Schmidt, H. E. Froehlich, C. Wagner, J. HilleRisLambers, J. Tewksbury, M. A. Harsch, and J. K. Parrish. 2015. Global change and local solutions: tapping the unrealized potential of citizen science for biodiversity research. Biological Conservation 181:236-244. http://dx.doi.org/10.1016/j.biocon.2014.10.021

Tregidgo, D. J., S. E. West, and M. R. Ashmore. 2013. Can citizen science produce good science? Testing the OPAL Air Survey methodology, using lichens as indicators of nitrogenous pollution. Environmental Pollution 182:448-451. http://dx.doi. org/10.1016/j.envpol.2013.03.034

Tulloch, A. I. T., H. P. Possingham, L. N. Joseph, J. Szabo, and T. G. Martin. 2013. Realising the full potential of citizen science monitoring programs. Biological Conservation 165:128-138. http://dx.doi.org/10.1016/j.biocon.2013.05.025

van der Velde, T., D. A. Milton, T. J. Lawson, C. Wilcox, M. Lansdell, G. Davis, G. Perkins, and B. D. Hardesty. 2017. Comparison of marine debris data collected by researchers and citizen scientists: Is citizen science data worth the effort? Biological Conservation 208:127-138. http://dx.doi.org/10.1016/j.biocon.2016.05.025

van Strien, A. J., C. A. M. van Swaay, and T. Termaat. 2013. Opportunistic citizen science data of animal species produce reliable estimates of distribution trends if analysed with occupancy models. Journal of Applied Ecology 50:1450-1458. http://dx.doi.org/10.1111/1365-2664.12158
Vianna, G. M. S., M. G. Meekan, T. H. Bornovski, and J. J. Meeuwig. 2014. Acoustic telemetry validates a citizen science approach for monitoring sharks on coral reefs. PLOS ONE 9: e95565. http://dx.doi.org/10.1371/journal.pone.0095565

Walker, J., and P. D. Taylor. 2017. Using eBird data to model population change of migratory bird species. Avian Conservation and Ecology 12(1):4. https://doi.org/10.5751/ACE-00960-120104 http:// dx.doi.org/10.5751/ACE-00960-120104

Wood C., B. Sullivan, M. Iliff, D. Fink, and S. Kelling. 2011. eBird: Engaging birders in science and conservation. PLoS Biology 9: e1001220. http://dx.doi.org/10.1371/journal.pbio.1001220

Yoccoz, N. G., J. D. Nichols, and T. Boulinier. 2001. Monitoring of biological diversity in space and time. Trends in Ecology and Evolution 16:446-453. https://doi.org/10.1016/S0169-5347(01) 02205-4
Editor-in-Chief: Keith A.Hobson Subject Editor: Scott Wilson
Sponsored by the Society of Canadian Ornithologists and Bird Studies Canada Parrainée par la Société des ornithologistes $d u$ Canada et Études d'oiseaux Canada

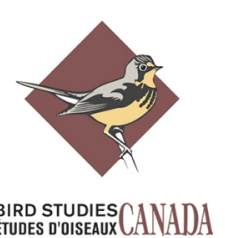


Appendix 1. The study sites that were included in the analyses. 'Locality' refers to the name of the greenspace in eBird.

Table A1.1. The greenspaces included in the main analysis of North America (i.e., United States and Canada).

\begin{tabular}{|c|c|c|c|c|c|c|c|c|c|c|c|}
\hline Locality & $\begin{array}{l}\text { eBird } \\
\text { Hotspot } \\
\text { ID }\end{array}$ & Latitude & Longitude & $\begin{array}{l}\text { Hotspot } \\
\text { area (Ha) }\end{array}$ & $\begin{array}{l}\text { Number of } \\
\text { checklists }\end{array}$ & Fall & Spring & Summer & Winter & Country & Urban Centre \\
\hline $\begin{array}{l}\text { A. D. Barnes Park } \\
\text { Boston Public }\end{array}$ & L200830 & 25.7341 & -80.311 & 27.2 & 1320 & 554 & 233 & 266 & 267 & $\begin{array}{l}\text { United } \\
\text { States } \\
\text { United }\end{array}$ & Miami, FL \\
\hline $\begin{array}{l}\text { Garden } \\
\text { Buena Vista Park }\end{array}$ & L209928 & 42.3536 & -71.071 & 9.6 & 450 & 121 & 243 & 41 & 45 & States & Boston, MA \\
\hline $\begin{array}{l}\text { Buena Vista Park } \\
\text { (SF Co.) } \\
\text { Calgary--Union }\end{array}$ & L508074 & 37.7678 & -122.44 & 16.67 & 177 & 33 & 52 & 49 & 43 & $\begin{array}{l}\text { United } \\
\text { States }\end{array}$ & San Francisco, CA \\
\hline $\begin{array}{l}\text { Cemetery } \\
\text { Centennial }\end{array}$ & L2390329 & 51.0292 & -114.06 & 35.08 & 363 & 146 & 64 & 88 & 65 & $\begin{array}{l}\text { Canada } \\
\text { United }\end{array}$ & Calgary, AB \\
\hline $\begin{array}{l}\text { Olympic Park } \\
\text { Constitution }\end{array}$ & L796074 & 33.7616 & -84.393 & 8.1 & 573 & 310 & 120 & 84 & 59 & States & Atlanta, GA \\
\hline $\begin{array}{l}\text { Gardens and } \\
\text { Reflecting Pool } \\
\text { Denver Botanic }\end{array}$ & $\mathrm{L} 473521$ & 38.8901 & -77.043 & 103 & 574 & 156 & 148 & 35 & 235 & $\begin{array}{l}\text { United } \\
\text { States }\end{array}$ & Washington, DC \\
\hline $\begin{array}{l}\text { Gardens and } \\
\text { Cheesman Park }\end{array}$ & L232994 & 39.7318 & -104.96 & 39.46 & 315 & 97 & 133 & 51 & 34 & $\begin{array}{l}\text { United } \\
\text { States } \\
\text { United }\end{array}$ & Denver, CO \\
\hline $\begin{array}{l}\text { Echo Park } \\
\text { Erie Street }\end{array}$ & L619767 & 34.0743 & -118.26 & 10.3 & 182 & 42 & 42 & 45 & 53 & $\begin{array}{l}\text { States } \\
\text { United }\end{array}$ & Los Angeles, CA \\
\hline $\begin{array}{l}\text { Cemetery } \\
\text { Freeway Park }\end{array}$ & L717897 & 41.4975 & -81.683 & 3.78 & 337 & 110 & 153 & 51 & 23 & $\begin{array}{l}\text { States } \\
\text { United }\end{array}$ & Cleveland, $\mathrm{OH}$ \\
\hline $\begin{array}{l}\text { (Seattle) } \\
\text { Green-Wood }\end{array}$ & L372668 & 47.6111 & -122.33 & 3 & 167 & 51 & 59 & 19 & 38 & States & Seattle, WA \\
\hline $\begin{array}{l}\text { Cemetery, } \\
\text { Brooklyn } \\
\text { Greenwood }\end{array}$ & L285884 & 40.6523 & -73.99 & 192.21 & 610 & 226 & 194 & 67 & 123 & $\begin{array}{l}\text { United } \\
\text { States } \\
\text { United }\end{array}$ & New York, NY \\
\hline $\begin{array}{l}\text { Memorial Park } \\
\text { Houston--White }\end{array}$ & L796467 & 32.7068 & -117.11 & 99.93 & 142 & 58 & 23 & 2 & 59 & $\begin{array}{l}\text { States } \\
\text { United }\end{array}$ & San Diego, CA \\
\hline $\begin{array}{l}\text { Oak Park } \\
\text { Humboldt Park, }\end{array}$ & L521123 & 29.7815 & -95.376 & 18.51 & 176 & 63 & 16 & 89 & 8 & $\begin{array}{l}\text { States } \\
\text { United }\end{array}$ & Houston, TX \\
\hline
\end{tabular}




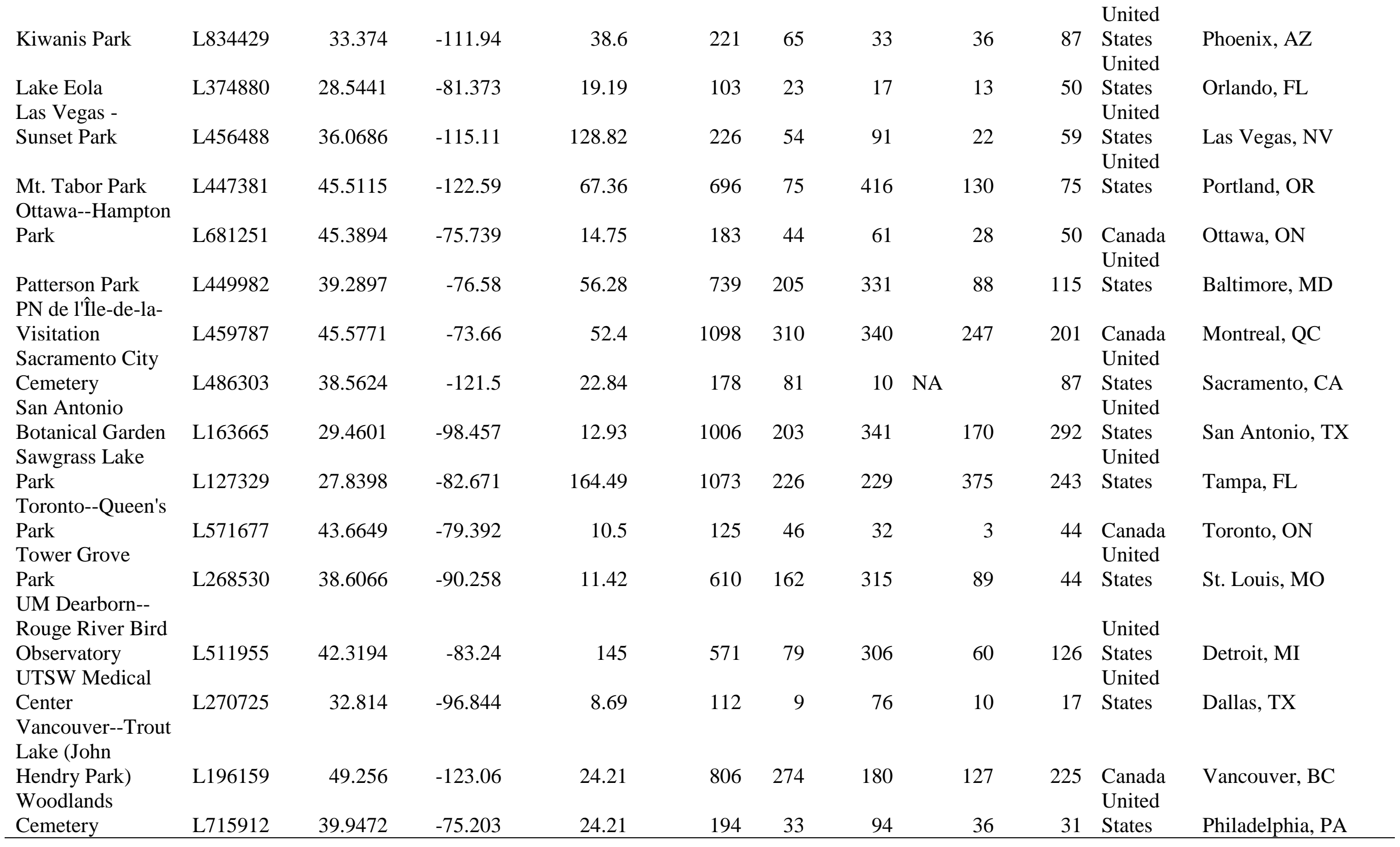


Table A1.2. The five global greenspaces that met the specified criteria, which were analysed and then compared with the North American greenspaces.

\begin{tabular}{|c|c|c|c|c|c|c|c|}
\hline Locality & $\begin{array}{c}\text { eBird } \\
\text { Hotspot } \\
\text { ID }\end{array}$ & Latitude & Longitude & $\begin{array}{c}\text { Hotspot } \\
\text { area }(\mathrm{Ha})\end{array}$ & $\begin{array}{l}\text { Number of } \\
\text { checklists }\end{array}$ & Country & Urban Centre \\
\hline Royal Botanic Gardens (Melbourne) & L919153 & -37.83 & 144.981 & 119 & 142 & Australia & Melbourne, VIC \\
\hline Parque Rufino Tamayo & L2875912 & 25.6444 & -100.33 & 21.2 & 181 & Mexico & Monterrey \\
\hline Hyde Park & L938388 & 51.508 & -0.164 & 276 & 176 & United Kingdom & London \\
\hline Centennial Park (Sydney) & L945869 & -33.898 & 151.234 & 191 & 180 & Australia & Sydney, NSW \\
\hline Fergusson College Campus & L3148022 & 18.5212 & 73.8337 & 62.3 & 164 & India & Pune, $\mathrm{MH}$ \\
\hline
\end{tabular}


Appendix 2. Results of investigating a seasonal component of the analysis.

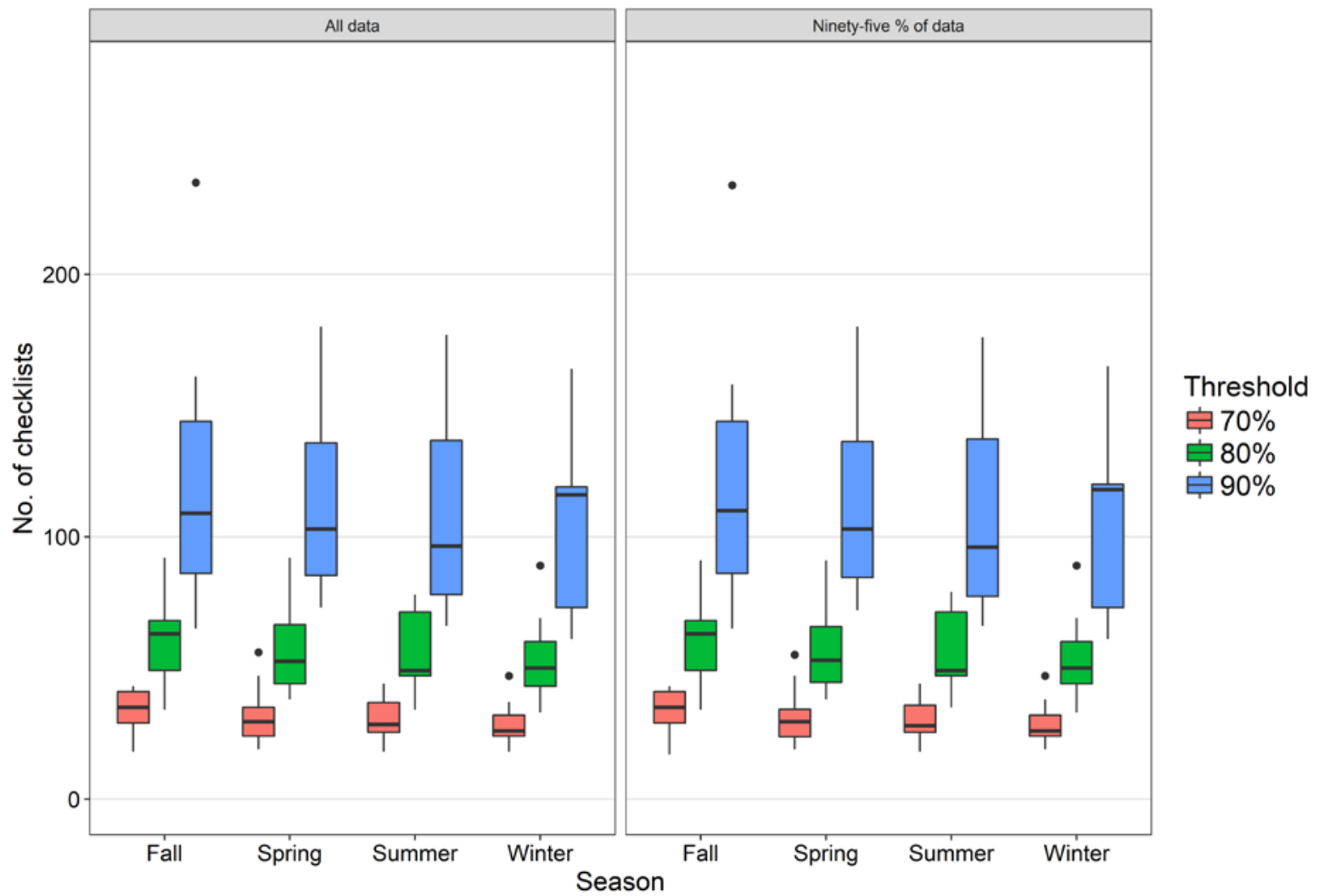

Figure A2.1. The difference among seasons and minimum number of checklists for species richness.

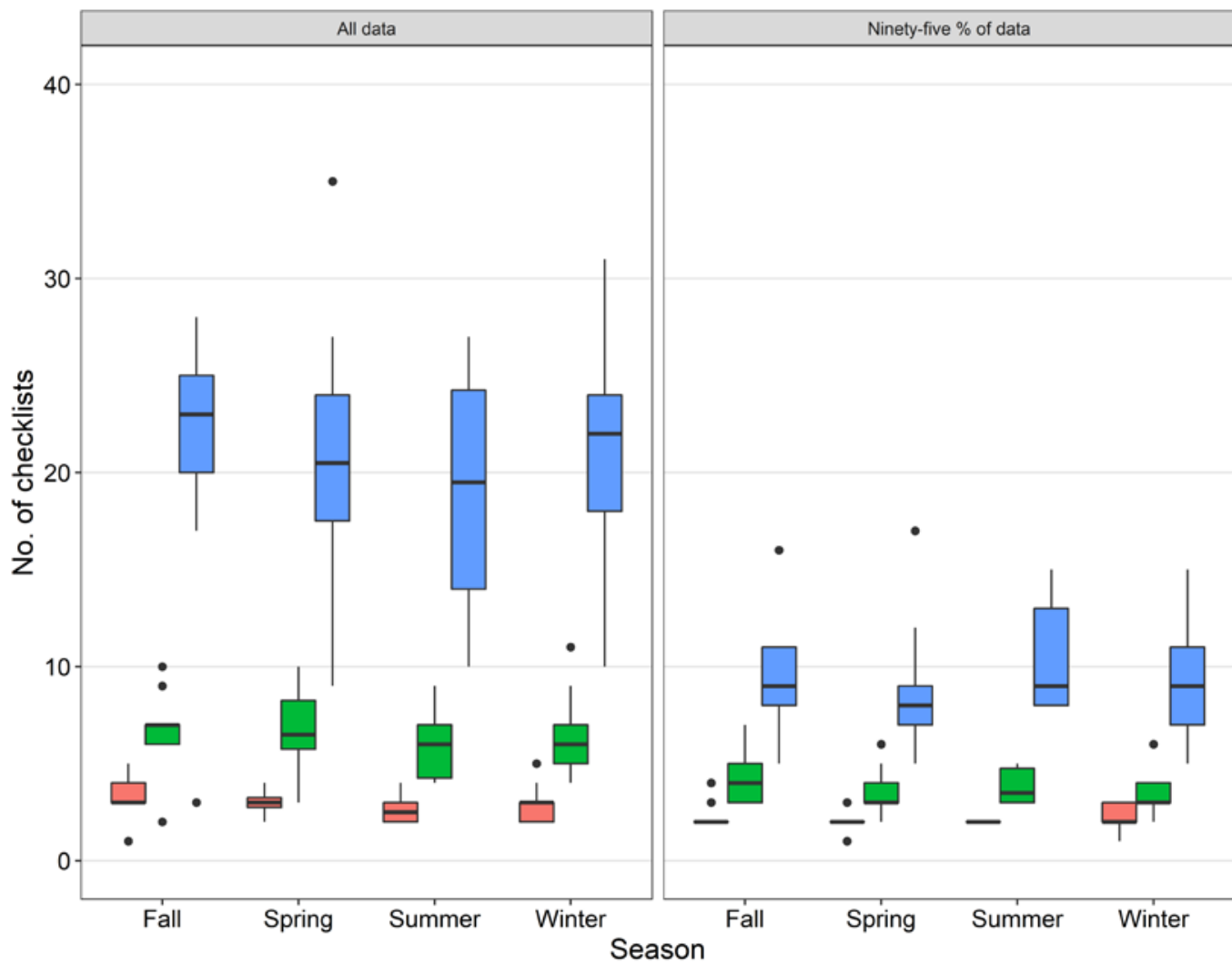

Threshold 追 $70 \%$ 官 $80 \%$ 官 $90 \%$

Figure A2.2. The difference among seasons and minimum number of checklists for species diversity. 


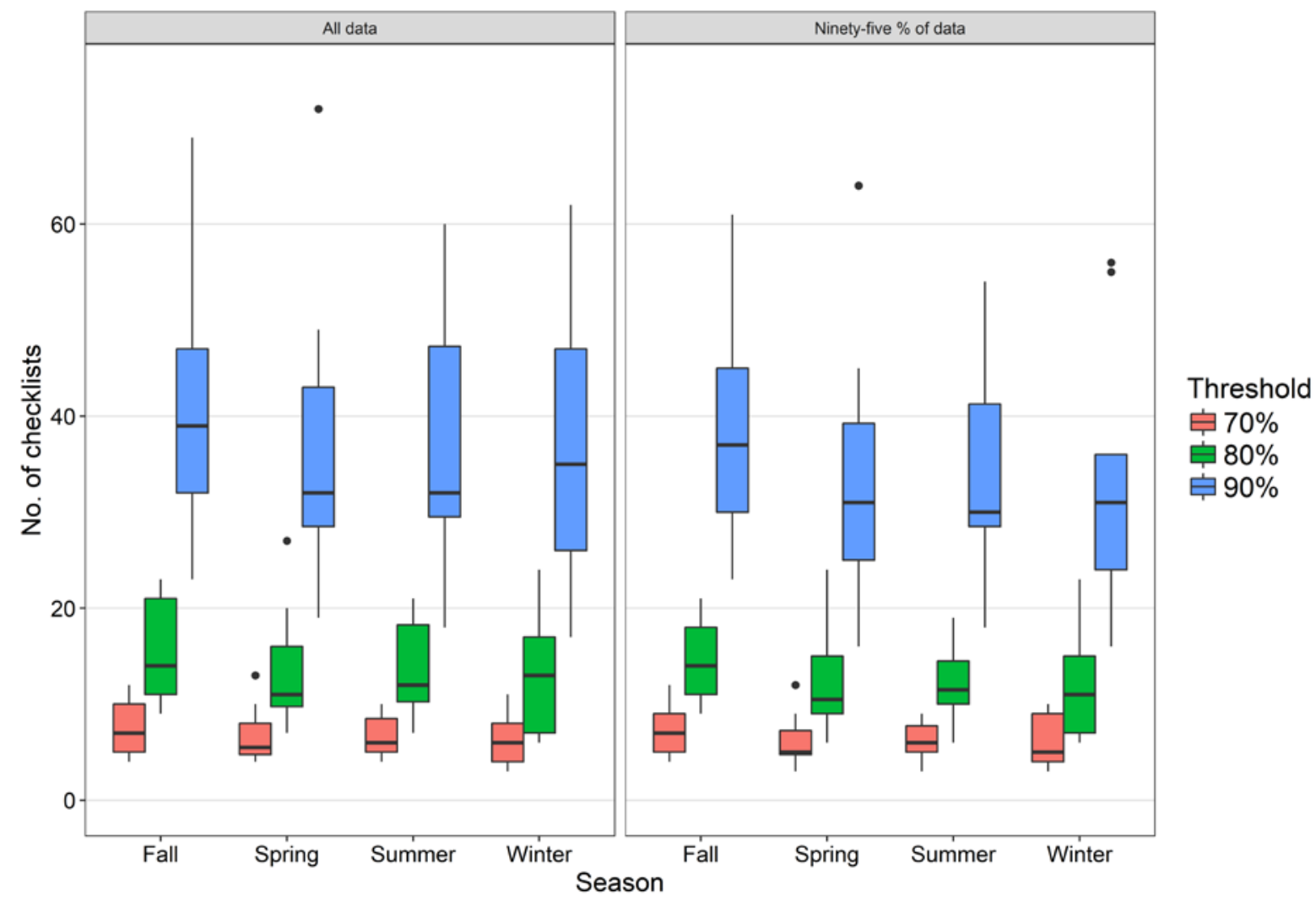

Figure A2.3. The difference among seasons and minimum number of checklists for autosimilarity (i.e., community composition). 

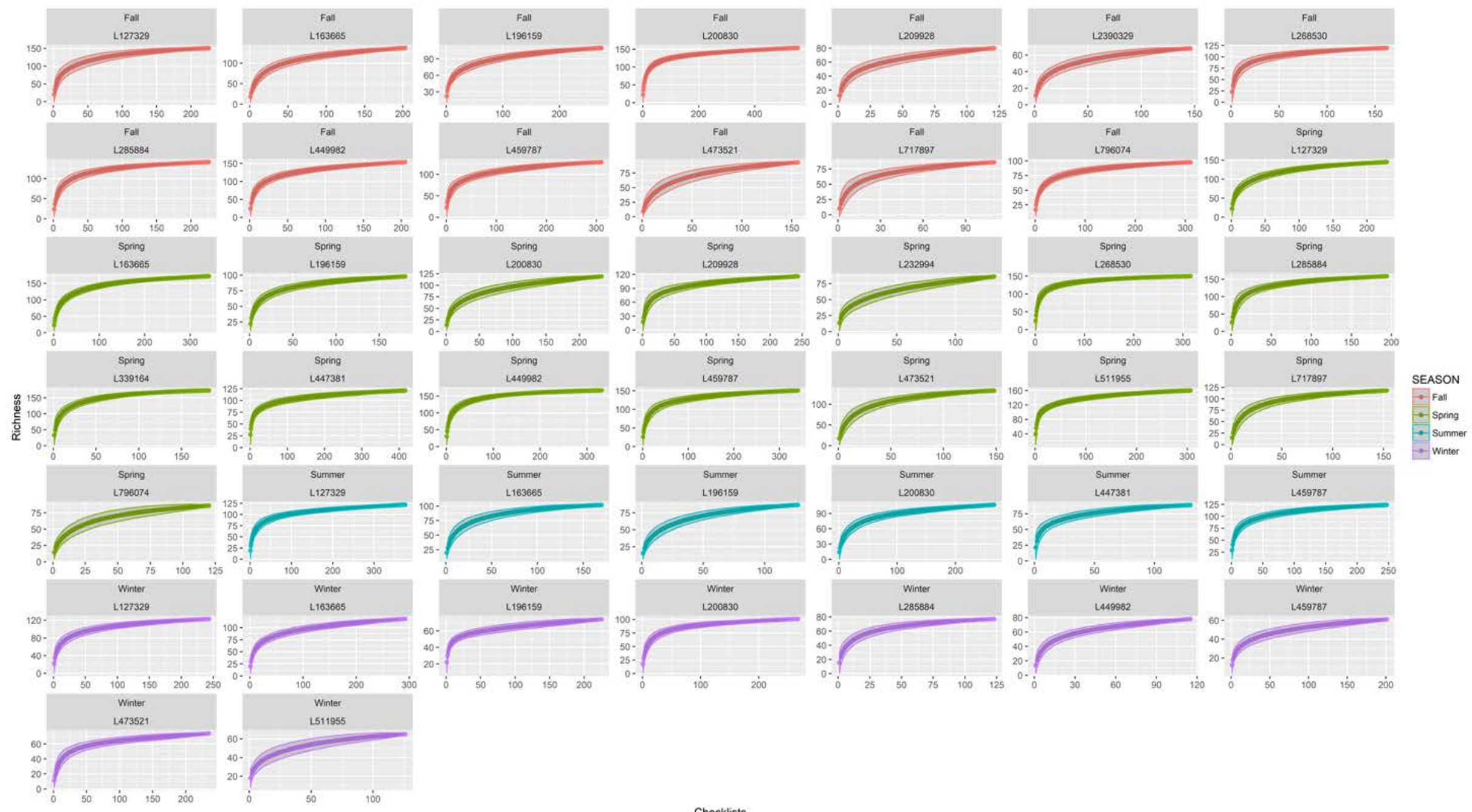

Figure A2.4. Species richness accumulation curves for each hotspot/season combination that had >100 checklists. 


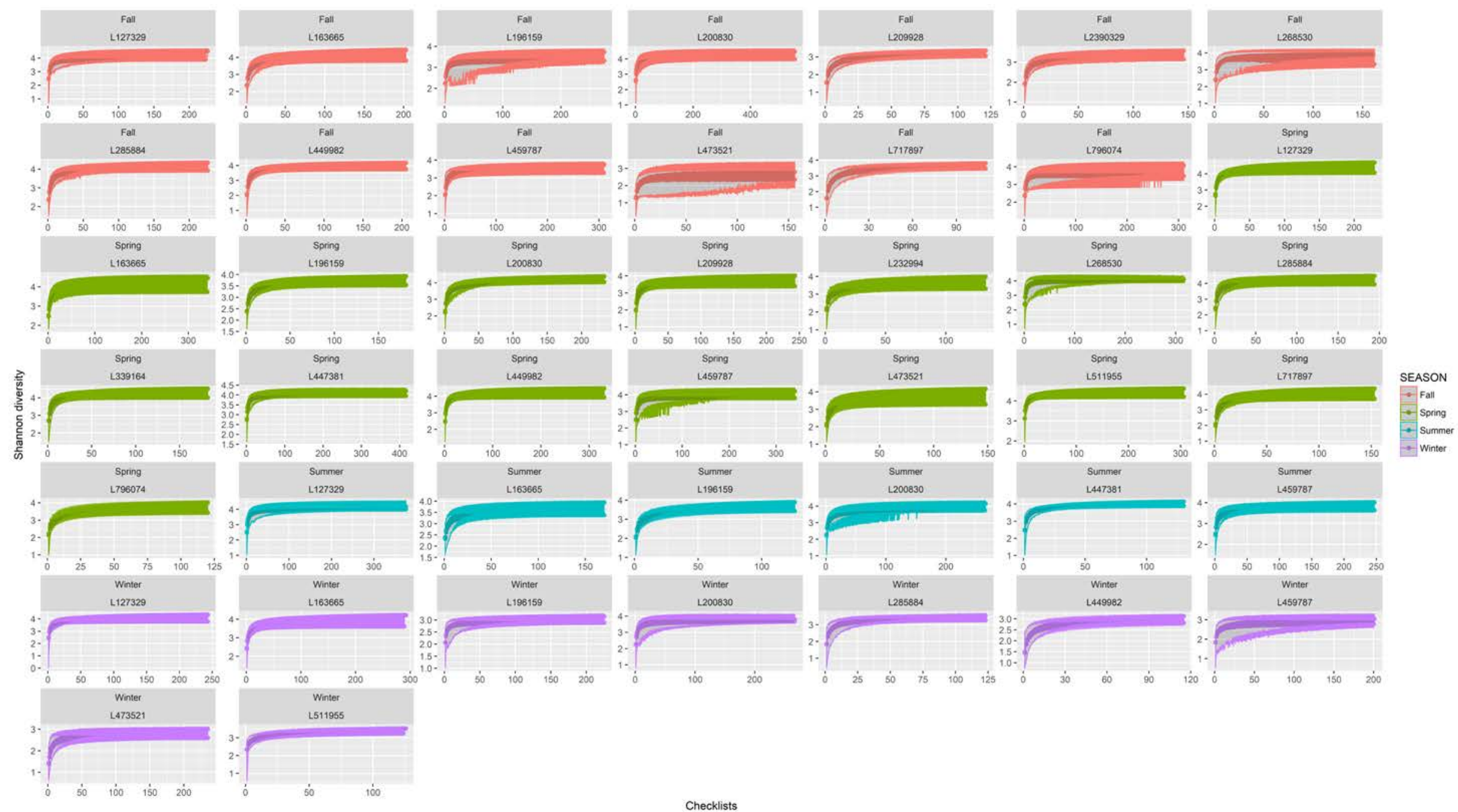

Figure A2.5. Species diversity accumulation curves for each hotspot/season combination that had >100 checklists. 


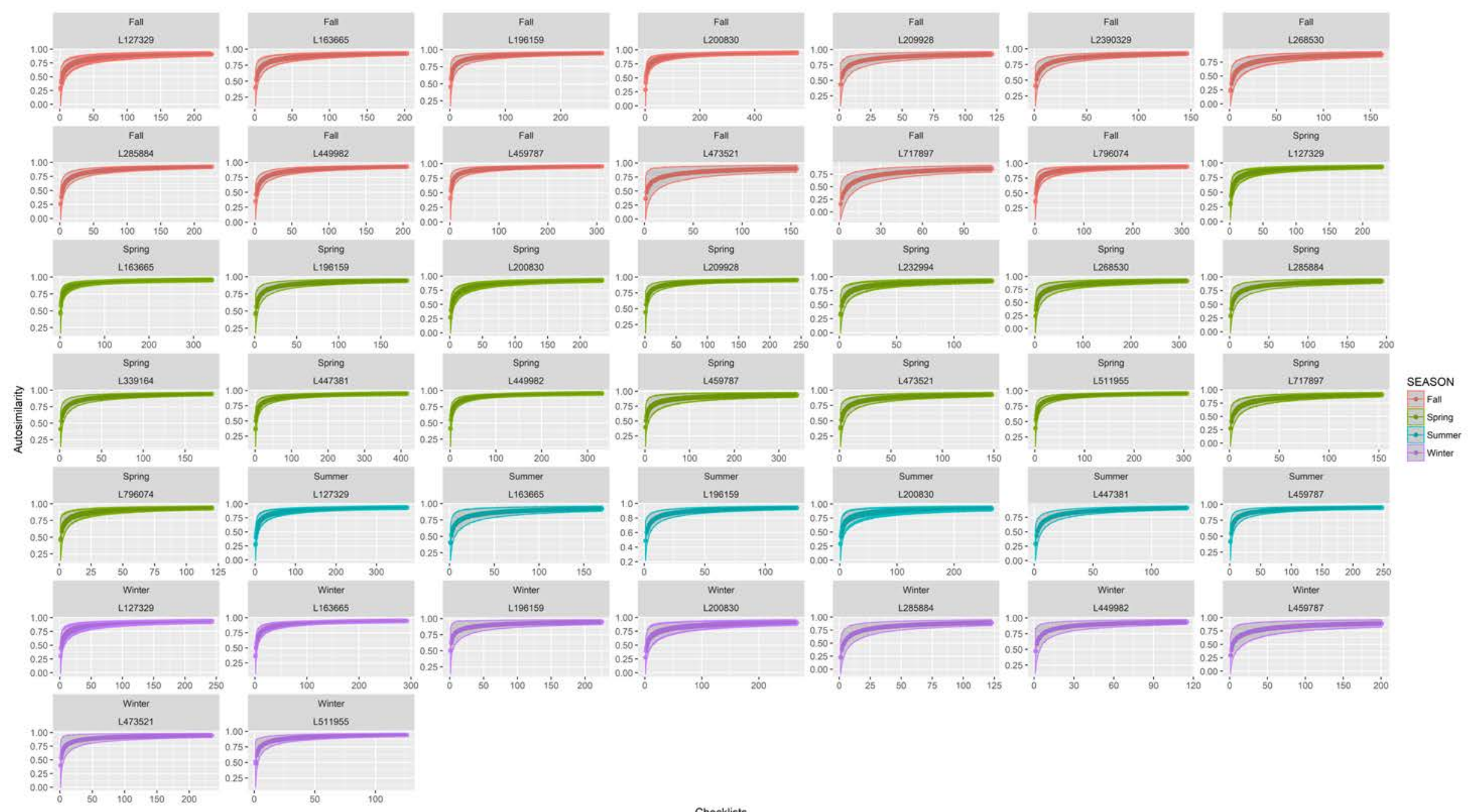

Figure A2.6. Autosimilarity curves for each hotspot/season combination that had $>100$ checklists. 
Appendix 3. The relationship between checklists and time.

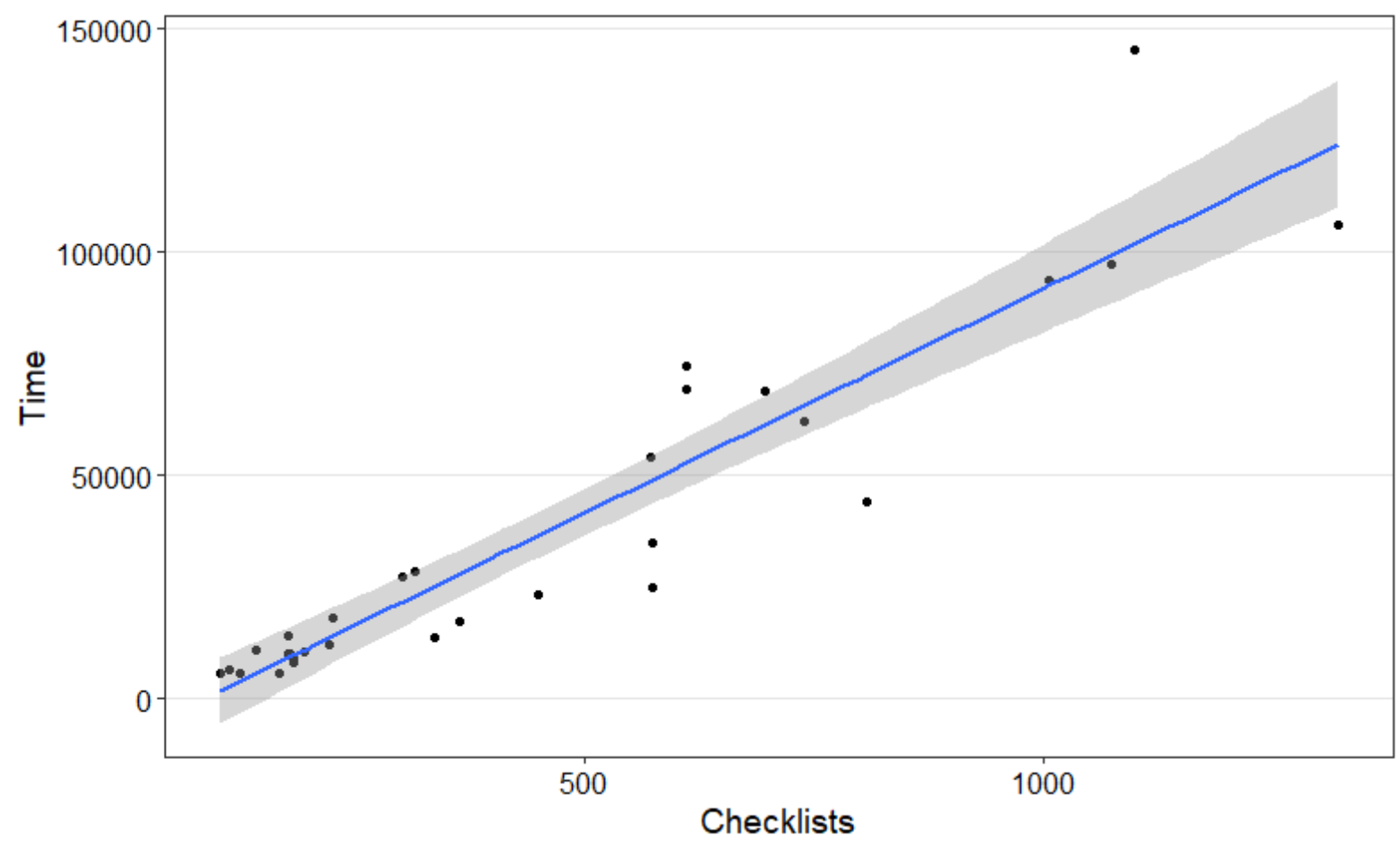

Fig. A3.1. There was a significantly positive relationship $(z=6.14, p<0.001)$ between sampling duration and the number of checklists at a greenspace. We presented the number of checklists as the response variable in our analyses. 
Appendix 4. Individual accumulation curves for each greenspace for species richness, species diversity, and community composition (autosimilarity). Results are presented for both separate analyses - the full dataset and those species recorded on $>5 \%$ of all checklists at the site.

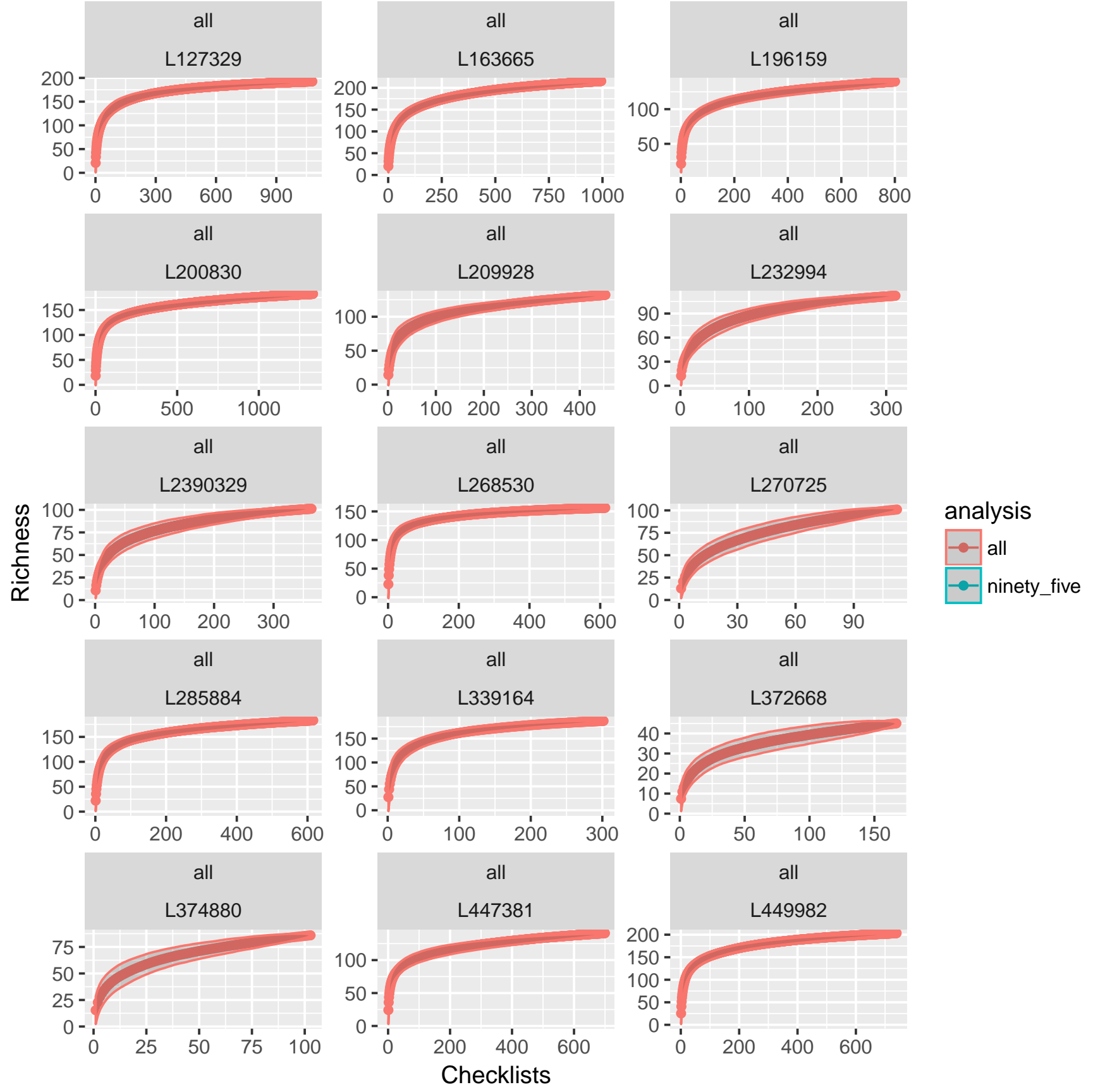




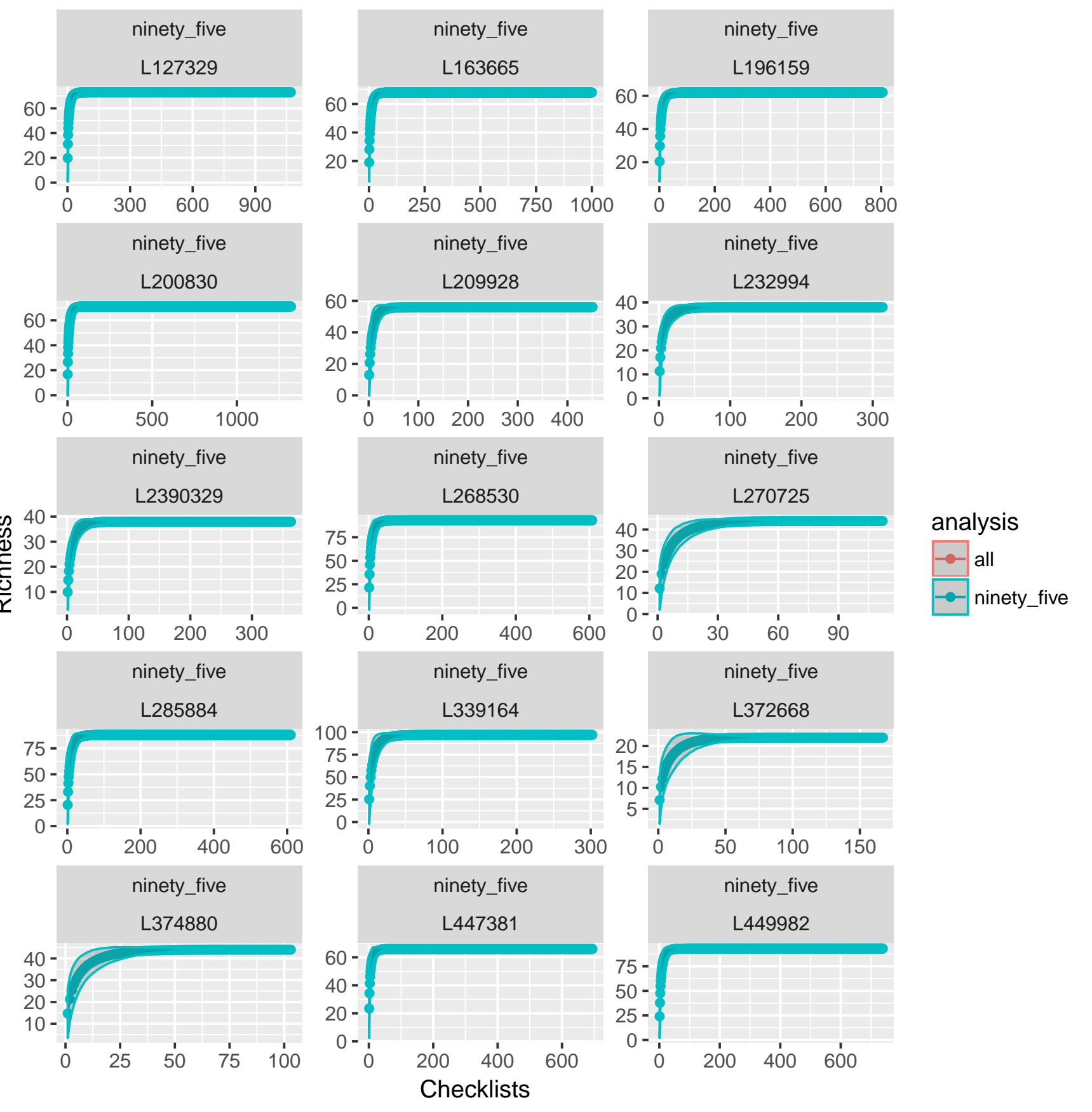



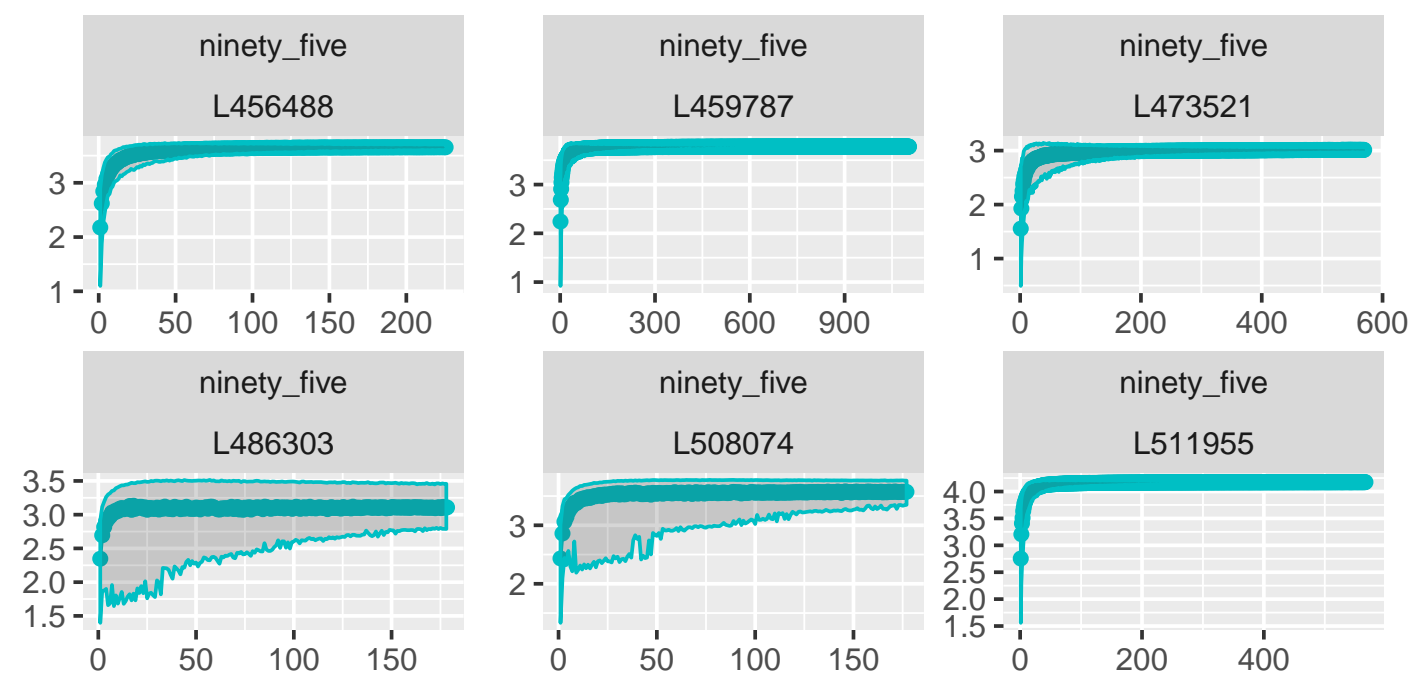

ninety_five
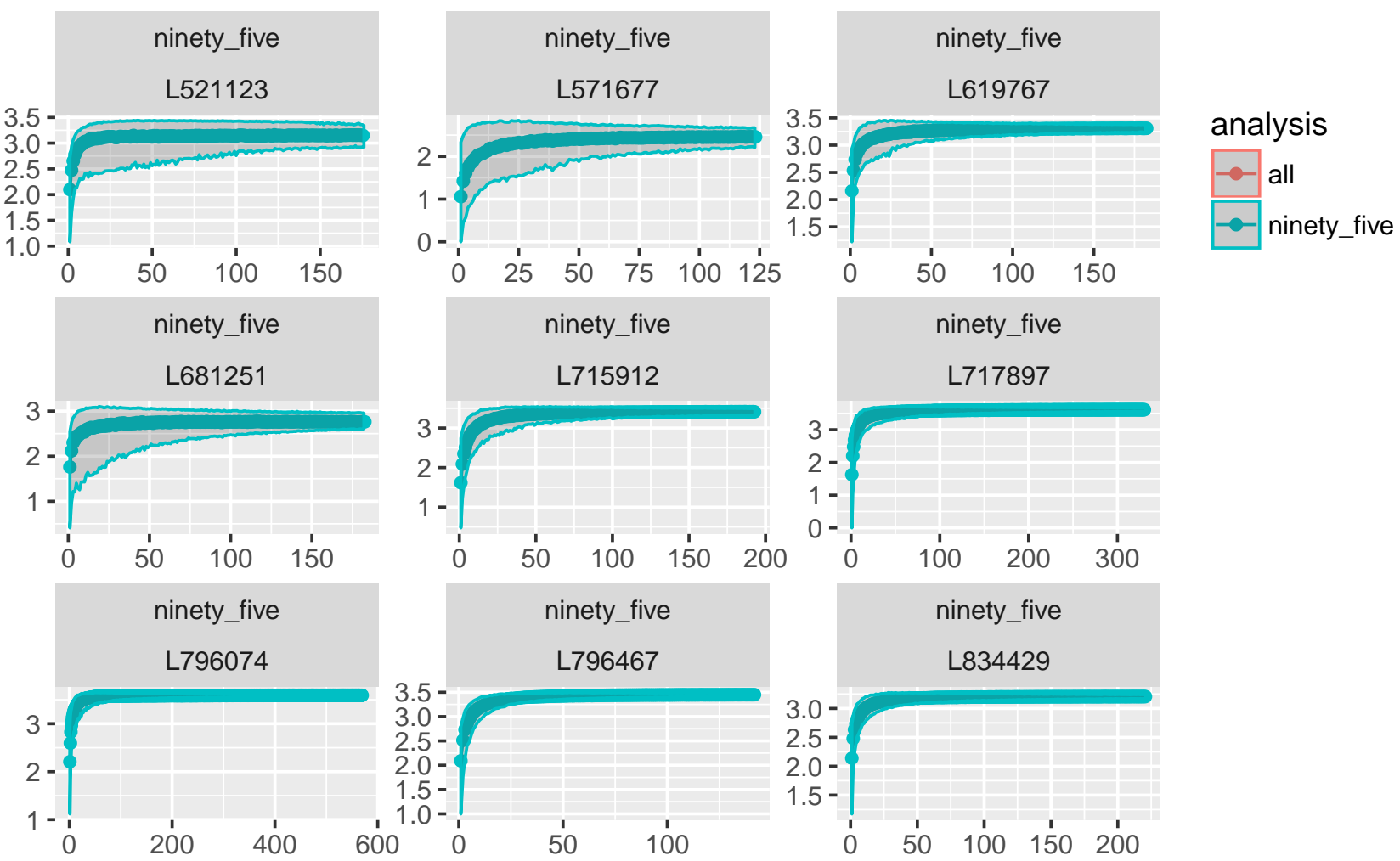

\section{Checklists}

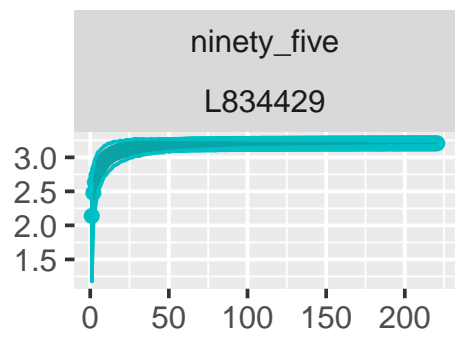

Figure. A4.2. Species diversity accumulation curves for each of 30 North American greenspaces, presented for both analyses. 


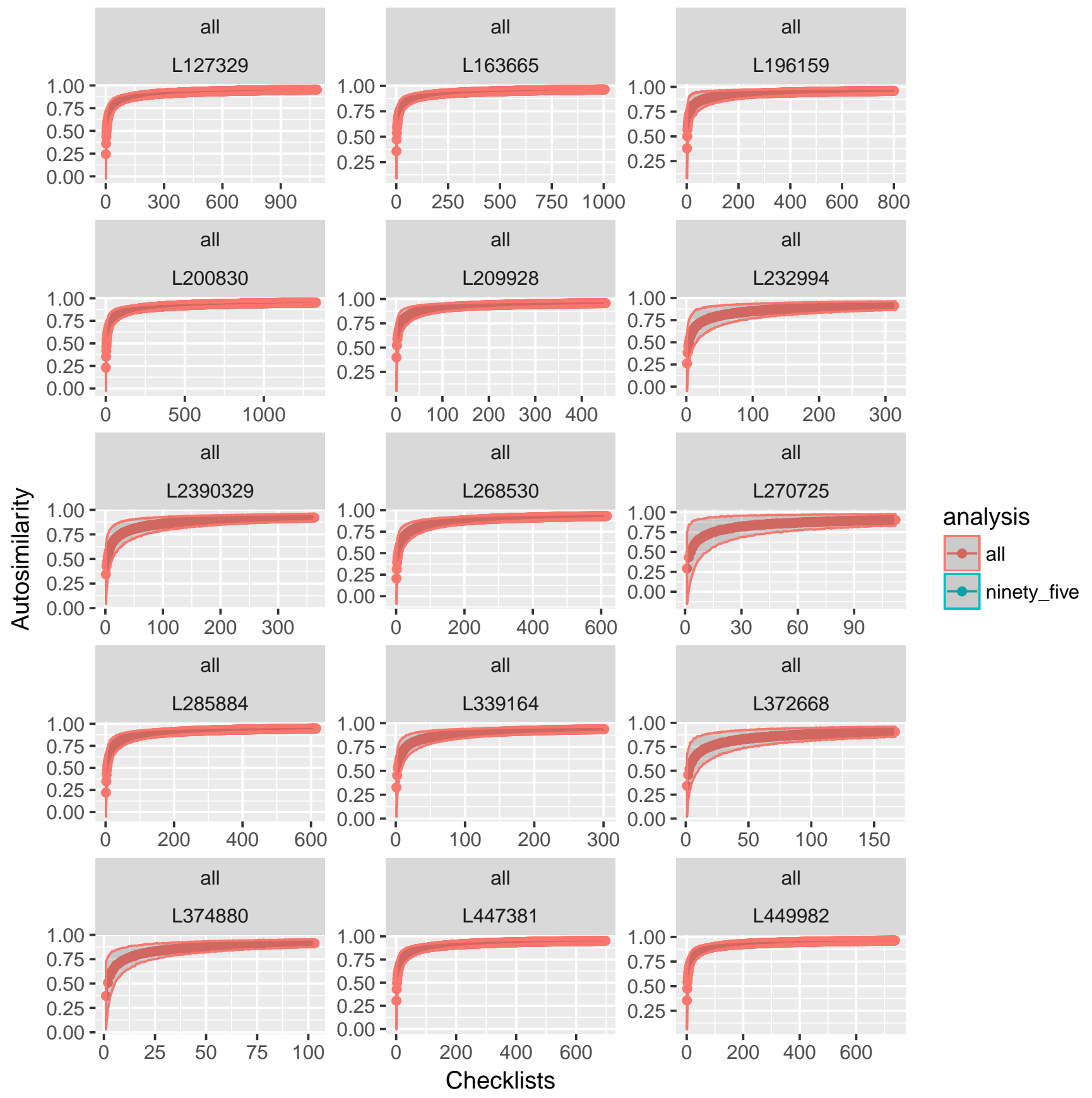




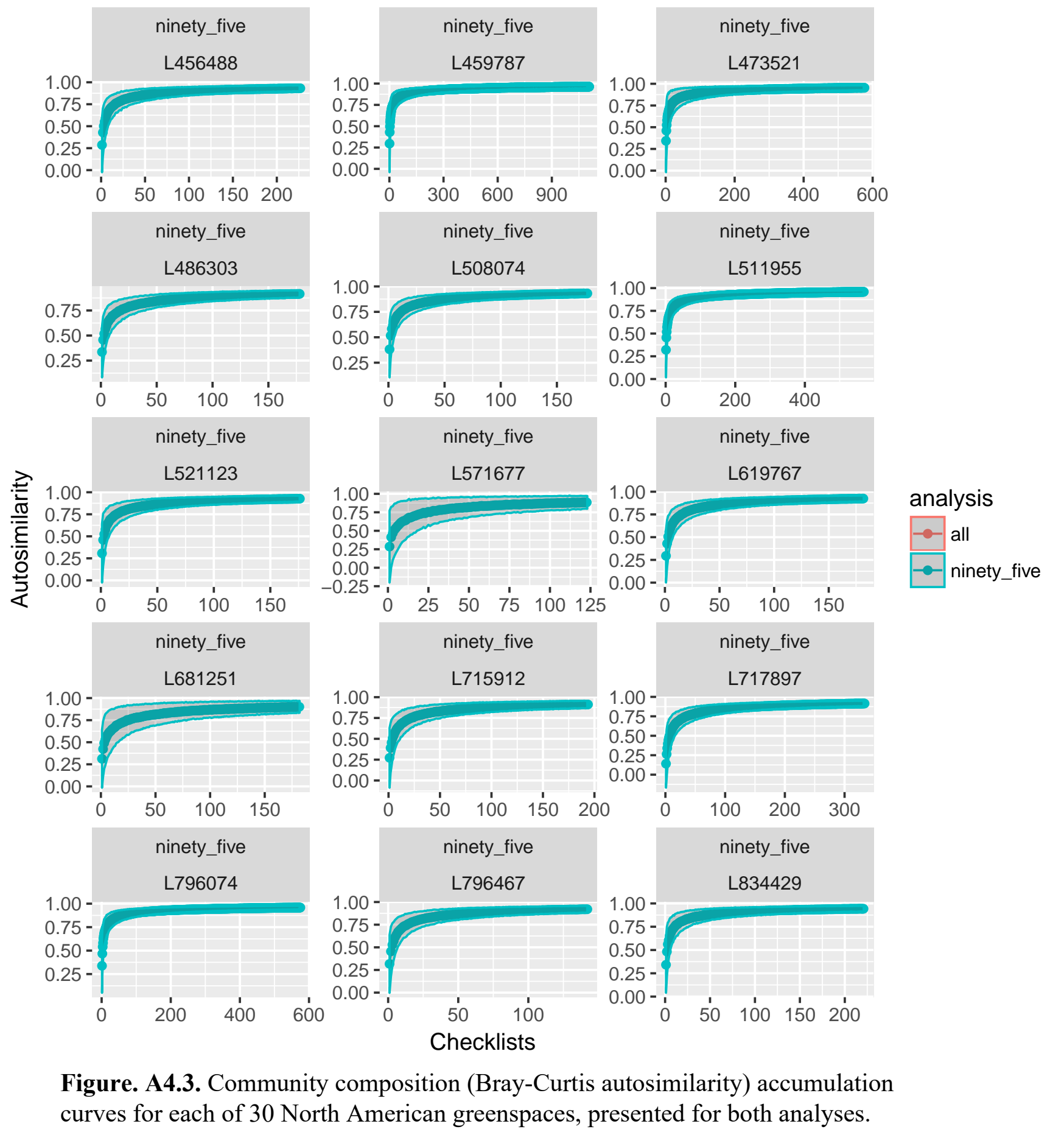


Appendix 5. Tutorial for an individual greenspace.

Please click here to download file 'appendix5.zip'. 